\title{
Development banks and the syndicate structure: Evidence from a world sample*
}

\author{
This Version: May 2020
}

\author{
Marta Degl'Innocentia, Marco Frigerio ${ }^{\mathrm{b}}$, Si Zhou ${ }^{\mathrm{c}}$
}

\begin{abstract}
Do development banks affect the structure of loan syndicates? We argue that development banks' participation in syndicates can reduce the lead banks' monitoring efforts and generate higher risk diversification across lenders. Using a global dataset of syndicated loans from 2001 to 2016 for 105 countries and 44,899 deals, we show that the lead banks decrease their loan shares and form less concentrated syndicates when development banks are participant lenders. These syndicates are also composed of a higher number of foreign lenders that retain greater loan shares. We also find that development banks are not associated with higher covenant violations. Our results are robust when accounting for relationship lending, asymmetric information within the syndicate, lenders' lending expertise, borrower opacity, types of loan, and ranking hierarchy in the syndicate, among others.
\end{abstract}

\section{JEL classification: D82; G21; G28}

Keywords: Syndicated loan market; Syndicate structure; Development banks; Foreign lenders; Loanlevel data

\footnotetext{
a Southampton Business School, University of Southampton, Highfield, Southampton SO17 1BJ, UK. Phone +44 -023-80598093. Email: m.deglinnocenti@soton.ac.uk

b Department of Economics, Management and Quantitative Methods, University of Milano, Via Conservatorio 7, 20122 Milan, Italy. Email: marco.frigerio@unimi.it

c School of Economics, Shanghai University, No.99, Shangda Road, Shanghai, 200444, P.R. China. Email: szhou@shu.edu.cn
}

\footnotetext{
${ }^{*}$ We thank Fabrizio Coricelli, Ettore Croci, Antonios Kalyvas, Renatas Kizys, Gabriele Lepori, Paulo Regis, Daniela Vandone and seminar participants at the University of Southampton and Shanghai University. We are solely responsible for all existing errors and omissions.
} 


\section{Introduction}

The growing literature on syndicate loans has emphasized the increasing importance of development banks in actively ameliorating political and country risk, signaling business opportunities, and attracting private capital particularly in cross-border lending to emerging and developing countries (e.g., Hainz and Kleimeier, 2012; Arezki et al., 2017; Broccolini et al., 2019). ${ }^{2}$ Since the early 2000s, development banks have played an increasingly important role in financing projects worldwide (e.g., OECD, 2018; Gurara et al., 2020). Particularly, loans with development banks' participation amounts to up to $15 \%$ of all cross-border lending and up to $10 \%$ of all syndicate loans during the years 2001-2016 with a peak of 35\% in South America and 20\% in Europe (see Table 1).

Development banks hold great appeal for the syndicate lending market for various reasons. They can arguably offer a "political umbrella" to the other participants in a syndicate by exerting a high bargaining power on governments' decisions and preventing the occurrence of adverse policies that would negatively affect their investment outcome (Hainz and Kleimeier, 2012; Arezki et al., 2017; Gurara et al., 2020). In addition, they are known for their reliability given by a relatively long track record; anti-cyclical behavior which makes them more resilient to capital shortage during financial turmoil; depth-local knowledge and strong monitoring capacity in countries and industries in which they are mostly active; and preferred creditor status which means they have their loans excluded from debt rescheduling (De Luna-Martinez and Vicente, 2012; Lazzarini et al., 2015; Mazzucato and Penna, 2016; Broccolini et al., 2019).

Consequently, can the reputation of development banks be instrumental in reducing asymmetry information problems between the lead bank, which is responsible for the information collection and monitoring activities, and the other participant lenders? Previous studies on syndicate loans widely acknowledge the importance of both the lead banks' and borrowers' reputations for

\footnotetext{
${ }^{2}$ Development banks are public sector or government-invested legal entities with an explicit policy mandate to spur the socio-economic development of a region, sector, or specific market segment.
} 
mitigating adverse selection and moral hazard problems in the syndicate (e.g., Dennis and Mullineaux, 2000; Esty and Megginson, 2003; Sufi, 2007; Gopalan et al., 2011; Lin et al., 2012; Cen et al., 2016 and Delis et al., 2020). Quite distinct from these studies, this paper explores whether the reputation of participant lenders can convey a positive signal about the quality of the loan and thereby reducing frictions between the lead bank and the other participant lenders. This can be reflected in the syndicate structure and composition which could be less concentrated and with a higher share risk across the syndicate.

In the syndication process, the lead bank that deals with the allocation of loan shares within the syndicate has the incentive to sell out a larger fraction of loans to other participants to reduce its risk exposure to the investment, particularly in case of bad or risky loans (Ivashina, 2009). ${ }^{3}$ As a result, the syndicate participants force the lead bank to exert as much monitoring effort as possible to reduce potential loan losses by retaining a greater fraction of the loan. In this paper, we hypothesize that the lead agent could leverage on development banks' well-known reputation and expertise in the lending market to reduce the gathering of information and monitoring efforts. This may represent an important avenue for the lead bank to alleviate potential asymmetric information problems with the borrower and the other participant lenders. Consequently, the lead bank does not need to retain a large portion of the loan to signal the borrower quality as development banks can play a certification role in business opportunities. Therefore, the fraction held by the lead bank in the syndicate should decrease because of the development bank's participation in the syndicate. This would imply a more dispersed syndicate and more diversification of risk exposure across lenders.

To empirically explore the validity of our arguments, we create a new worldwide dataset. Specifically, we gather data from three different sources. First, we map the development banks by referring to the worldwide list of development banks provided by $\mathrm{Xu}$ et al. (2019). We further

\footnotetext{
${ }^{3}$ The syndicate loan contract is signed by all the participants. "Each participant is responsible for a share of its loan and the terms of the loan are identical for all syndicate members” (Sufi, 2007, p.633).
} 
refine the initial selection of development banks through manual inspection, online research, and a general review of annual reports and publicly available information. Then, we use LPC-Dealscan which includes the most comprehensive and historical loan-deal information available on global loan markets. Third, we match the loans with firm-specific accounting information from Compustat and with macroeconomic (country-year) variables from several freely available sources, such as the Worldwide Governance Indicators. Our data encompass 44,899 syndicated loans over the period 2001-2016 for 105 countries.

Our empirical evidence is consistent with our expectations. Our results show that when development banks are participant lenders the lead banks retain lower loan shares in the syndicates by approximately 2.87 percentage points which is a $10 \%$ decrease on an average lead bank's share of $28.55 \%$ in our sample (or $\$ 5.7$ million in economic terms). In addition, we further show that syndicates with development banks are $11 \%$ less concentrated using the Herfindahl index and have an average increase of approximately $62 \%$ in the number of lenders. These results suggest that syndicates with development banks consist of a more diffuse loan ownership and, therefore, present a greater diversification of risk exposure across lenders.

Furthermore, we explore whether development banks also affect the composition of the loan syndicate by focusing on foreign lender participation. In this respect, our findings show that the number of foreign lenders increases by approximately $141 \%$ in syndicates with development banks. In addition, foreign banks are more likely to retain a greater loan share in such syndicates by approximately 23\% compared to the mean of the entire sample (or $\$ 10.3$ million for the average loan). Consequently, foreign lenders appear to contribute to a more diffuse syndicate structure.

Our identification method accounts for potential unobserved variables that might bias our inferences, i.e., country, year, industry and loan purpose effects, as well as firms, banks, loans and countries' time-varying characteristics. We also control for previous relationships of the lead bank 
with the borrowing firm and with the other participating lenders, and for development banks' type (namely national and multinational development banks). ${ }^{4}$

We run a battery of robustness tests to verify our findings. First, to account for the possibility that our baseline results could be driven by time-variant country and industry characteristics, we incorporate country multiplied by year and industry multiplied by year fixed effects in the estimations. We also saturate the model with lead bank multiplied by year fixed effects. A further concern could be that development banks may prefer certain role functions in a syndicate. For example, by taking more senior role functions in the syndicate, their participation could be systematically associated with a lower lead agent's monitoring effort. We test this alternative explanation and find that the distribution of roles undertaken by development banks is like those of other participant lenders.

Another potential source of concern for our empirical analysis is that both development banks' participation in a syndicate and the syndicate structure could be associated with the borrowing firms' fundamental characteristics. To address this potential selection bias, we employ a matching technique to construct suitable control/treatment samples for the comparison of loan structures. Next, we rerun our analysis by removing private firms from the sample which typically suffer from more asymmetric information.

In addition, it could also be that development banks’ participation is associated with a lower monitoring effort by the lead agent because the other lenders have expertise with respect to the borrowing firm's country and industry. Development banks could also prefer certain lenders. We address this by re-estimating the baseline model removing loans with a high presence of lenders with a high expertise in the borrowing firm's country and industry. Furthermore, we examine whether development banks participate in syndicates when there are certain lenders. In this case the syndicate structure could be affected by both development banks and the other lenders associated

\footnotetext{
${ }^{4}$ National and multinational development banks could indeed exert a different impact on the syndicate structure and composition because of their variety of expertise, reputation and exposure to local political pressure.
} 
with them. Finally, we run a placebo test by randomly assigning the development banks' dummy to banks in our sample, and we also account for the possible impact of 2007-2009 financial crisis on the main findings. Overall, our findings are robust to all these tests.

As additional analysis, we examine whether other lenders participate in syndicates because they are already familiar with the borrower and/or the lead bank. Moreover, we explore whether the participation of development banks is associated with a higher probability of covenant violations due to their selection of risky loans.

Our paper contributes to the existing literature in several ways:

First, we contribute to the stream of research that considers the effect of reputation on the syndicate structure. Specifically, Sufi (2007) empirically shows that both the lead bank and borrower can mitigate asymmetric information concerns in the syndicate and thus reduce the loan share held by the lead bank. Consistently, other studies (e.g., Dennis and Mullineaux, 2000; Gopalan et al., 2011; Delis et al., 2020) examine the effect of lead lenders' market reputation on the syndicate structure. Conversely, we explore the effect of the reputation-signaling role of development banks as participant lenders on the syndicate structure.

Next, our study highlights new evidence on the role of development banks in the syndicate market. Very recent studies (Broccolini et al., 2019; Gurara et al., 2020) have examined the effect of multilateral development banks' participation on loan pricing and mobilization of private resources to developing countries. In addition, Hainz and Kleimeier (2012) find that political risk affects the participation of development banks in syndicated lending. Differently to these works, our research is the first to study the effect of development banks' participation on the syndicate structure. We do not also restrict our analysis to specific geographical areas or type of loans.

Finally, we add new understanding to the strands of literature that examine the syndicate participation rate of foreign lenders in the syndicate markets (Stein, 2002; Esty, 2004; Mian, 2006; Haselmann and Wachtel, 2011; Lin et al., 2012; Claessens and van Horen, 2014). Previous studies argue that foreign banks are less willing to lend to physically and culturally distant firms as 
screening and monitoring activities are costly (Mian, 2006). In the case of monitoring-intensive relationship loans, foreign lenders are more reluctant to invest abroad. As a result, cross-border syndicates tend to be relatively concentrated and composed of domestic banks that are geographically close to the borrowing firms and that have lending expertise related to the industries of the borrowers (Lin et al., 2012). This paper offers evidence that development banks' participation is associated with a higher number (and a larger loan share) of foreign participants. Arguably, development banks' expertise - particularly political influence - can reduce some of the foreign lenders’ risk concerns.

This paper is organized as follows. Section 2 presents the sample and discusses the development banks' participation in a syndicate; Section 3 discusses the methodology; Section 4 presents the main results, while Section 5 shows robustness checks. Section 6 focuses on additional analysis which consists of investigating the effect of development banks' participation on covenant breaches and other lenders’ participation choices, and Section 7 concludes the paper.

\section{Data}

\subsection{Sample construction}

Our empirical analysis begins with an accurate taxonomy of development banks worldwide, since there is not a universally recognized and readily available scheme (or classification) for these financial intermediaries. We start the identification and mapping of development banks by referring to the worldwide list of development banks provided by $\mathrm{Xu}$ et al. (2019), which considers a development bank to be any institution that satisfies the following three criteria: i) is legally independent and self-sustaining; ii) pursues public policy objectives, and (iii) receives government support. The list encompasses 539 development banks that are part of either membership lists of 
development financial institutions, ${ }^{5}$ or other associations that could include development financial institutions among other members. ${ }^{6} \mathrm{We}$ also devoted considerable effort to refine the initial selection of development banks through manual inspection, online research and a general review of annual reports and publicly available information.

We exclude from our final sample Islamic banks, micro-financing institutions and universal banks. Differently from previous studies (Broccolini et al., 2019; Gurara et al., 2020), this paper also encompasses development banks at national and sub-national levels and not only multilateral organizations. This is an important feature of this paper as national and sub-national institutions represent $90 \%$ of all the existing development banks.

Following this procedure, we identify 554 development banks in 155 countries. Specifically, these development banks encompass 498 national or sub-national development banks (e.g. German KfW and the Korea Development Bank), and 56 multilateral (global or regional) development banks that are international financial institutions chartered by two or more countries (e.g. World Bank and the European Investment Bank). Data on syndicated loans comes from the DealScan database between 2001 and 2016. ${ }^{7}$ We find that 81 development banks (of the 554 previously mapped) participated at least once in a loan syndicate. ${ }^{8}$

We include in our sample only the loans for which the borrowing firms' data can be matched to Global Compustat and for which the financial variables employed in the study are available. ${ }^{9}$ Furthermore, we match the resulting dataset with macroeconomic (country-year) variables come from several freely available sources such as World Bank, Heritage Foundation, Doing Business, Worldwide Governance Indicators. Table 4 presents the definitions of each variable. Loan-related information is

\footnotetext{
${ }^{5}$ For the scope, Xu et al. (2019) consider the World Federation of Development Financing Institutions, including the Association of African Development Finance Institutions, the Association of Development Financing Institutions in Asia and the Pacific, the Association of National Development Finance Institutions in Member Countries of the Islamic Development Bank, and the Association of Development Finance Institutions in Latin America.

${ }^{6}$ For example, the Long-Term Investors Club (LTIC) and the European Association of Public Banks (EAPB).

${ }^{7}$ Sample starts from 2001 as development banks exhibit emerging renaissance since the beginning of the 2000s.

${ }^{8}$ List of development banks is reported in Appendix B.

${ }^{9}$ We extract bank loan contract information from LPC-Dealscan and link loan-level data to Compustat firm data following Chava and Jarrow (2004), and then use the Dealscan-Compustat Link extended by Michael Roberts (Links are accessed through: http://finance.wharton.upenn.edu/ mrrobert/styled-9/styled-12/index.html).
} 
retrieved from DealScan. Overall, our sample consists of 44,899 syndicated loans over 105 countries.

\subsection{Development banks' 'participation in syndicates: main trends}

Table 1 summarize the development banks' participation in our sampled syndicated loans. It also reports the percentage weight of syndicated loans with development banks in terms of number of loans and loan amount by macro region by considering the borrower's country over the period 20012016. Specifically, the deals with at least one development bank as a lender amount to $9.4 \%$ of all the syndicated loans (8.8\% after excluding deals where the development bank is the lead bank).

\section{[Insert Table 1 about here]}

Furthermore, Table 2 shows the number of loans and loan amounts participated in by at least one development bank per macro-region. We notice that multilateral development banks participate in syndicates where the borrower is mainly located in South America, Eastern Europe, Africa and Middle East. Instead, national development banks appear to be active in Western Europe and Far East and Central Asia. At the industry level, national development banks invest more in: (i) Mining, and (ii) Transportation, Communications and Utilities industries. In contrast, multilateral development banks intervene more in the primary sector (Agriculture, Forestry and Fishing).

\section{[Insert Table 2 about here]}

Finally, Table 3 presents the descriptive statistics and compares the main variables of interest in syndicates, respectively, without development banks' participation (No DBs) and with development banks' participation (DB Participant). Loan deals with development banks' participation have longer maturities and are larger in size, with a higher participation rate of foreign lenders than those formed only by private banks (Table 3). Development banks also appear to engage in deals with borrowers larger in size and with more tangibility. 


\section{[Insert Table 3 about here]}

\section{Methodology}

To empirically test our hypothesis that development banks' participation in syndicate loans is associated with more dispersed ownership and diversification of risk exposure across lenders, we analyze the syndicated loan structure. Specifically, following previous studies (e.g., Sufi, 2007; Ivashina, 2009; Lin et al., 2012; Delis et al., 2020), we employ the following variables for the syndicate structure: i) the logarithm number of lenders (in addition to the lead bank); ii) the share of the loan held by the lead lender; iii) the Herfindahl-Hirschman index (HHI) of the syndicate, which shows the concentration of holdings within a loan syndicate; iv) the number of foreign lenders; and v) the share of the loan held by foreign lenders. To identify the main lead agent of a loan with multiple lenders, we follow the procedure suggested by Chakraborty et al. (2018). For each facility, the lead agent is identified by the lender with the highest rank following the ten-part ranking hierarchy developed by Chakraborty et al. (2018). ${ }^{10}$

Using a cross section of loans for multiple years, we employ the following model to examine development banks’ impact on syndicate structure,

$$
S_{i, t}=\alpha_{i}+\beta_{i} \text { DB participant }{ }_{i, t}+\beta_{i} X_{i, t-1}+Z_{i}+\varepsilon_{i, t}
$$

where $S$ represents the syndicate loan structure. The main variable of interest, DB participant, is equal to one if at least one development bank is among the participants (excluding the lead bank) in the loan syndicate, and $X$ is the vector of control variables including loans, borrowers and country characteristics. $Z$ denotes a vector of fixed effects and $\varepsilon$ is the remainder disturbance. In line with

\footnotetext{
10 The ranking hierarchy consists of the following roles: 1) lender is denoted as “Admin Agent”, 2) lender is denoted as "Lead bank", 3) lender is denoted as "Lead arranger", 4) lender is denoted as "Mandated lead arranger", 5) lender is denoted as "Mandated arranger", 6) lender is denoted as either "Arranger" or "Agent" and has a "yes" for the lead arranger credit, 7) lender is denoted as either "Arranger" or "Agent” and has a "no" for the lead arranger credit, 8) lender has a "yes" for the lead arranger credit but has a role other than those previously listed ("Participant" and "Secondary investor" are also excluded), 9) lender has a "no" for the lead arranger credit but has a role other than those previously listed ("Participant" and "Secondary investor" are also excluded), and 10) lender is denoted as a "Participant” or "Secondary investor".
} 
Bharath et al. (2011), we consider a period of five years to define country and industry expertise and all the relationship lending variables. ${ }^{11}$

We also include the variable, The lead bank is a former lender, to account for previous relationship lending over the last five years between the lead bank and the borrowing firm. Additionally, following Ivashina (2009), we consider syndicate-specific reputation variables Syndicate reputation: lead to participant and Syndicate reputation: reciprocal - which refer to previous connections between syndicate members. Furthermore, we add the variable, The lead bank is foreign, which is a dummy equal to one if the lead bank is foreign.

We use a variety of control variables to capture various characteristics and factors other than the main variables of interest. We account for borrower fundamentals including the private firm dummy, logarithm of total asset, return on asset (ROA), leverage and tangibility. We also add loan characteristics including loan amount, loan maturity, covenants, collateral, institutional investors, $>1$ loan tranche and term loan in the equation. Other control variables include macro-economic factors that capture the economic and financial development at the country level. These variables encompass log GDP per capita and domestic credit to GDP (\%). Finally, we also use lead bank, loan purpose, country, year and industry (division) fixed effects to saturate our model from differences in loans, countries, year and industries. All variable definitions are reported in Table 4.

If the development banks play a role in ameliorating asymmetric information concerns and risks within syndicates, then we should expect the DB participant to exert a positive effect on the syndicate structure. Instead, if the presence of a development bank in the syndicate curtails asymmetric information concerns or has no effect, then the $D B$ participant should be negatively related to or having no effect on the syndicate structure.

\section{[Insert Table 4 about here]}

\footnotetext{
${ }^{11}$ In unreported tests, we also consider an alternative horizon of three years prior to the loan, and the results are consistent. Tables are available upon request.
} 


\section{Empirical Analysis}

\subsection{Main findings}

In this section we examine whether and to what extent the participation of a development bank in a syndicate affects the syndicate structure at the single loan level.

Table 5 presents the results when estimating equation (1). Overall, our results suggest that the effect of development banks’ participation in the syndicates are not only statistically significant but also relevant from an economic perspective. Column 1 shows that development banks' participation increases the number of lenders in the syndicate by more than four lenders per loan which corresponds to an average of $62 \%$ compared to the average size of the entire sample. Column 2 indicates that development banks' participation decreases the loan shares held by the lead bank by 2.87 percentage points. Given that the lead banks have an average share of $28.55 \%$ in our sample (see Table 3), this finding implies a decrease of approximately $10 \%$ of the lead bank's loan share (or $\$ 5.7$ million for the average loan). Using the Herfindahl index, Column 3 also shows that syndicates with development banks are $11 \%$ less concentrated compared to other syndicates $(0.03 / 0.27)^{12}$

As regards the syndicate composition, Column 4 of Table 5 shows that development banks' participation in syndicates are associated with higher numbers of foreign lenders (approximately 3.66 lenders). This corresponds to an average increase of foreign lenders by approximately $141 \%$ in syndicates (3.66/2.59). In addition, foreign banks are more likely to retain a greater loan share in such syndicates by approximately 23\% (5.2/22.56) compared with the sample mean (or $\$ 10.3$ million in economic terms). All the coefficient estimates are statistically significant from zero at the 1\% significance level.

\footnotetext{
${ }^{12}$ We also rerun the main analysis with Syndicate size (number of lenders) and Number of foreign participant lenders as dependent variables by using a Poisson pseudo-maximum likelihood regressions with multi-way fixed effects (Correia et al., 2020). As an alternative estimation model, we also employ a fractional regression model for the specifications with Lead Share, Concentration (Herfindahl) and Foreign Share as dependent variables. The estimates confirm the baseline model results. The results are available upon request.
} 
Overall, the results suggest that loans with a development bank are less concentrated, with a lower fraction of the loan retained by the lead bank, and with more foreign lenders' participation. This suggests that the lead bank can form larger syndicates and is required to exert less due diligence and monitoring efforts when a development bank is a participant lender. In line with our expectations we also find that these syndicates have a more diffused structure and are characterized by larger fractions of loan held by foreign lenders.

Concerning other control variables, Table 5 shows that particularly the lead bank's reputation, calculated following Ivashina (2009) as the maximum number of links between the lead bank and the members of the syndicate, largely increases the number of lenders by approximately eight lenders and reduces the lead bank loan share by more than $20 \%$.

\section{[Insert Table 5 about here]}

\subsection{Development banks’ type and lender roles}

It is possible that our previous findings are dominated by certain types of development bank. For example, global (regional) development banks tend to have wider international visibility and reputation which broadcasts a stronger signal for business opportunities in the lending market than is the case with national (or sub-national) development banks. Consequently, they could have stronger impact on the syndicate structure. To verify this possibility, we rerun the analysis by considering the development banks’ type.

Specifically, we create an indicator variable, $D B$ is national (or sub-national), which is equal to one if the development bank is established by the central or local government of a single country, and zero if established by two or more countries (i.e. multilateral development bank). Instead, the indicator, Global (or regional) $D B$, is equal to one if the development bank is either a global or regional development bank. We further consider whether development banks are in the same county of the borrowing firm. The indicator, Participation of a foreign $D B$, is equal to one if the development bank has its headquarters in a different country with respect to the borrowing firm. 
Instead the indicator, Participation of a domestic $D B$, is equal to one if the development bank has its headquarters in the borrowing firm's country.

Table 6 reports the estimation results of the baseline model conditional on all sampled loans having development banks participants. ${ }^{13}$ Our results suggest that domestic development banks and foreign development banks appear to exert a similar effect on the syndicate structure. However, we find that syndicates with a foreign development bank have a higher number of foreign lenders by approximately 2.54 lenders per loan compared to syndicates with a national development bank, as shown in Column 3. In addition, foreign development banks increase the share held by foreign lenders by approximately 28.57 percentage points compared to national development banks. As shown in Panel B of Table 6, global and regional development banks (Global (or regional) DB dummy) strongly decrease the lead agent's loan share by approximately 10.66 percentage points and increase the foreign lenders' loan share by approximately 13.70 percentage points compared to national or sub-national development banks (National (or sub-national) DB dummy).

\section{[Insert Table 6 about here]}

It is possible be that development banks participate in syndicates only if they can cover senior roles, such as co-leads and co-agents. Therefore, the effect of the $D B$ participant dummy could be due to such a senior role rather than development banks per se. In this case, the lead banks could retain a lower fraction of the loan because they delegate some monitoring activities to development banks. To verify this possibility, we compare the distribution of roles undertaken by development banks and other participant lenders in syndicates. Figure 1 shows a similar pattern between development banks and other participant lenders, suggesting that development banks do not have a specific preference for syndicates’ senior roles.

\section{[Insert Figure 1 about here]}

\footnotetext{
${ }^{13}$ We find that both types of development bank have a significant impact on the syndicate structure when we consider the entire sample.
} 


\section{Robustness checks}

This section presents a battery of additional exercises we carried out to rule out alternative stories as well as to assess the robustness of our findings. First, we address the concerns associated with the potential endogeneity issues. Accordingly, we run additional tests to alleviate potential bias in our estimates due to omitted variables. Specifically, we consider the country multiplied by year and industry multiplied by year fixed effects to account for the omitted country and industry timevariant characteristics that might bias our results. We also control for lead bank multiplied by year fixed effects to capture supply-side explanations of the findings, including changes in the business model/capital availability of banks. In addition, we account for selection bias issues and the preference of the development banks for certain lenders. Finally, we run a placebo test and exclude private firms and the 2007-2009 financial crisis from the sample.

\subsection{Additional fixed effects}

In our baseline regression we include country and industry fixed effect to control for possible timeinvariant country and industry characteristics that could affect both a development bank participation choice and the syndicate structure of a loan. However, it could also be that timevariant country and industry characteristics might both affect a development bank participation in the syndicate and the syndicate structure at the same time. To mitigate such concern, we add country multiplied year and industry multiplied year fixed effects.

As a further control we saturate the model with lead bank multiplied by year fixed effects. In this way we account for any time-variant lead bank-specific characteristics that might jointly affect development banks' participation in a syndicate and the syndicate structure.

All the results reported in Table A1 of Appendix A corroborate the baseline finding of Table 5 as the coefficient of $D B$ participant remains statistically significant at the $5 \%$ significance level and above, with very similar magnitudes as those in the baseline regressions. 


\subsection{Sample selection issues}

The association between development banks and the syndicate structure could be due to endogenous selection of firms based on their fundamental characteristics.

To address this potential selection bias, we match the development bank participated loans (treatment sample) with loans that have similar characteristics but without development banks' participants (control sample). Specifically, we first form a sample of loans with borrowers in the same region and 2-digit industrial codes (such as Asia and Europe) as borrowers in the treatment sample. We then estimate the probability of having a development bank in a syndicate conditional on loan-level characteristics (i.e. maturity and amount), and borrower-level fundamentals (i.e. total assets, ROA, leverage and tangibles), in the year prior to receiving the loan. For each loan in the treatment sample, we select up to five loans in the control sample (i.e. without development banks' participation), using the closest propensity scores from the probit estimation. Table 7 reports the estimates obtained rerunning our regressions within the matched sample. All the results corroborate our previous findings as the effect of $D B$ participant remains statistically significant at and above the $5 \%$ significance level.

\section{[Insert Table 7 about here]}

A further concern could be related to the fact that development banks engage in loans with more severe asymmetric information problems between lenders and borrowers. A less concentrated syndicated ownership could therefore reflect a lender's' diversification strategy in response to asymmetric information problems. To mitigate this concern, we rerun our analysis by excluding private firms from the sample, since they typically suffer from more asymmetric information compared to public firms (Dennis and Mullineaux, 2000; Lee and Mullineaux, 2004; Sufi, 2007). As "private" firms lack publicly available information, participant lenders depend more on the lead bank for monitoring activities and their ability to collect detailed information on those firms (Sufi, 2007). The estimates reported in Table A2 confirm our previous findings. 


\subsection{Development banks and other lenders}

In this subsection we explore whether our main results are driven by the fact that development banks participate in loans where the other lenders also have an expertise in the country/industry of the borrowing firm. To test this, for each other lender, we calculate two dummies ('Top' country and 'Top' industry) that are equal to one if, respectively, industry and country of the borrowing firm are the industry (2-digit SIC) and country with the highest participation of lender $i$ in the last five years before the syndication year $t$ of the loan $j$, and zero otherwise. Then, we rerun our test in Table 5 by considering only the loans where the percentages of lenders with 'Top' country expertise and 'Top' industry expertise that equal to one are both below the mean of the entire sample. Results are consistent as reported in Table A3 of the appendix.

Further, development banks might prefer to participate in syndicates when there are certain lenders. In this case, there could be a development bank-lender match. We verify whether this issue occurs in our sample by comparing each lender's participation rate for syndicates with development banks and without development banks. Specifically, we compute the lender's participation rate (lender PR) by considering the number of syndicates participated in by each lender over the total number of syndicates. Two different rates are computed for each lender: one for syndicates with no DBs on board (DB participant $=0$ ) and one for syndicates with at least one DB on board (DB participant=1). Figure A1 shows that lenders participation rate is not driven by the presence of development banks. Lenders that invest more frequently in the syndicates with development banks have a similar participation rate in syndicates without development banks.

\subsection{Sample variations}

A further concern is that the baseline results could be affected by the 2007-2009 financial crisis. Previous studies document that development banks' investments have a long-horizon and countercyclical pattern and offer support when private financing is scarce (Chelsky et al., 2013; Humphrey and Michaelowa, 2013; Galindo and Panizza, 2018). Large banks could be more willing to deal with 
development banks during such periods of financial turmoil and instability. Therefore, we account for alternative capital supply explanations of the findings by re-running our models excluding the 20072009 financial crisis (Garcia-Appendini and Montorial-Garriga, 2013). The results are robust as reported by Table A4 of the appendix.

Finally, to address the possible concern that our main findings are driven by potential sample variation, we rerun the baseline model by randomly assigning the $D B$ participant dummy (sampling with replacement within each year) for 1,000 random resamples. Table A5 shows that the coefficient on the DB participant dummy estimated from these 1,000 Monte Carlo simulations is not significantly different from zero for any of our dependent variables. This placebo test confirms that the effects observed from the participation of development banks in a syndicate are unusual compared to the effects from the participation of other banks.

\section{Additional Analysis}

\subsection{Participant choice}

Although we account for participant lenders' lending experience (with respect to countries and industries) in Table A3, it could be that lenders participate in syndicates because they are already familiar with the borrower and/or the lead bank. To account for this, we run an additional regression to examine whether $D B$ participant dummy affects the probability of private lenders being chosen as participants once several characteristics are controlled for, including the familiarity of lenders themselves with the borrower and the lead bank. ${ }^{14}$

Furthermore, we examine how the probability of both domestic and foreign lenders being chosen as a participant varies by the type of development bank to complement the analysis reported in Table 6. Following Sufi (2007), we consider as the "potential" participant choice set all the

\footnotetext{
${ }^{14}$ Consistent with Sufi (2007), we focus on the efficiency of syndicate membership rather than investigating how that efficiency is reached.
} 
private lenders with at least $0.5 \%$ market share in the year of the loan in at least one macro region. We exclude all development banks from this analysis.

Specifically, we use a linear probability model (LPM) where the dependent variable takes the value of one if the private commercial bank $i$ participates in the syndicated loan $j$ at year $t$, and zero otherwise. The main variables of interest are: (i) Participation of a domestic national DB, which is equal to one if there is at least one national development bank in the same country of the borrower that takes part in the loan, and zero otherwise; (ii) Participation of a foreign or global DB, which is equal to one if there is at least one foreign or multilateral development bank (with respect to the borrower's country) that takes part in the loan, and zero otherwise; (iii) The indicator, The lender is foreign, is equal to one if the lender is a foreign bank, and zero otherwise; (iv) The indicator, 'Top' industry for the lender, is equal to one if the industry of the borrowing firm is the industry (2-digit SIC) with the highest participation of lender $i$ in the last five years before the syndication year $t$ of the loan $j$, and zero otherwise; (v) Lender former participant for borrower and Lender former lead bank for borrower are dummy variables that equal to one if the lender lent to the same borrower in the past five years (as either a participant lender or lead bank respectively), and zero otherwise; (vi) Lender on syndicate with the lead bank in the last five years is an indicator that equals to one if the lead bank has collaborated in the past five years with the lender, and zero otherwise. As in equation (1) we also consider the following variables for the Lead bank: The lead bank is foreign and The lead bank is a former lead bank for borrower. In addition, we add the Big lead bank dummy that is equal to one if the lead bank is one of the five lenders with the highest market share in the syndicated loans market within the time period of the analysis. Furthermore, we account for the possibility that the lead bank is listed (listed lead bank dummies). Moreover, we account for the size and level of capitalization of other lenders (respectively logarithm of total asset and capitalization ratio). Finally, we include the same borrower, loan and country control variables and fixed effects of equation (1). 
Table 8 presents the estimates. The results show that domestic national development banks significantly increase the probability of a domestic lender ending up in a syndicate by 7 percentage points while foreign or global (or regional) development banks increase such probability by 3 percentage points (Columns 3 and 4). Conversely, foreign or global (or regional) development banks reduce the likelihood that a domestic lender will join the syndicate by 4 percentage points if the lead bank is foreign. In contrast, foreign or global (or regional)) development banks increase the likelihood that foreign lenders will participate in a syndicate by around 4 percentage points (Column 6). Furthermore, domestic national development banks are more likely to be associated with a higher foreign lenders' participation in a syndicate only if the lead bank is not foreign (Column 4). ${ }^{15}$

In general, foreign or global (or regional) development banks are of greater appeal to foreign lenders. A possible explanation could be that domestic development banks do not have the same international reputation as foreign or global (or regional) development banks. Moreover, foreign lenders may be skeptical that domestic development banks could be more subject to local political pressure. This could result in misallocation of funding to politically connected firms and, consequently, to higher loan failure (e.g., Ades and Di Tella, 1997; La Porta et al., 2002; Sapienza, 2004; Dinc, 2005; Faccio, 2006 and Frigerio and Vandone, 2020).

As an additional exercise, we find that lenders located in a different country with respect to the borrowing firm are less likely to be chosen as a lender by almost 10 percentage points. We also show that former relationship with the borrower is relatively more important than industrial expertise for other financial institutions. Specifically, if a lender has been the former lead bank for the borrower firm in the last five years, the probability of being chosen as a lender in a syndicate is higher by more than 15 percentage points. However, such increase is even higher than 40 percentage points if the lender has been the former participant for the borrower firm in the last five

\footnotetext{
${ }^{15}$ Indeed, when both the lead bank and the participant development bank are foreign (or multilateral), the participation of domestic lenders tends to decrease by around 4 percentage points (= $3.12-7.31$ in Column 4$)$ to the benefit of foreign lenders' participation.
} 
years. Finally, previous development bank-lead bank relationships only marginally affect participation choice.

\section{[Insert Table 8 about here]}

\subsection{Covenant violations}

We further explore whether the participation of development banks is associated with a higher probability of covenant violations due to their selection of risky loans. There is a stream of research claiming that development banks are not better selectors of borrowers than is the case with private commercial banks. Specifically, these studies argue that development banks may misallocate credit by either bailing out companies that would otherwise fail or channeling funds to firms for political advantages/purposes (Ades and Di Tella, 1997; La Porta et al., 2002; Faccio, 2006). Therefore, the recipients of credit would not be selected based on the quality of their entrepreneur projects but for political reasons.

To account for this issue, we explore whether development banks’ participation in a syndicate is associated with a higher likelihood of covenant violations. Specifically, following Demiroglu and James (2010), we consider the current ratio and Debt/EBITDA as financial covenants. We also include Interest coverage in the analysis as this is one of the most commonly used financial covenants in the loans included in our sample. Using yearly Compustat data, we define a violation as any year in which the covenant variable breaches the covenant threshold specified in the loan agreement during the three-year period following the origination of the loan. Table 9 shows that development banks' participation in a syndicate is not associated with a higher probability of covenant violations.

\section{[Insert Table 9 about here]}

\section{Conclusion}

In this paper we explore whether development banks affect the syndicate structure. Specifically, we investigate whether syndicates with development banks are less concentrated and with more 
diversification of risk exposure across lenders. Using a novel dataset of syndicate loans for development banks across 105 countries from 2001 to 2016, we find strong evidence that syndicates with a development bank as a participant lender have a more diffuse loan ownership and consist of a double number of participant lenders, particularly foreign lenders. In these syndicates the lead bank retains a lower loan share by approximately 2.87 percentage points, which is a $10 \%$ decrease on an average lead bank’s share of $28.55 \%$ in our sample (or $\$ 5.7$ million in economic terms). Our findings suggest that a higher foreign lenders' participation in syndicates with development banks could drive a greater diversification of risk exposure across lenders. Consistently, our findings show that the number of foreign lenders increases by approximately $141 \%$ at the mean in syndicates with development banks. In addition, foreign banks are more likely to retain a greater loan share in such syndicates by approximately 23\% compared to the mean of the entire sample (or $\$ 10.3$ million in economic terms). Therefore, the presence of a development bank in a syndicate appears to lead to a greater diversification of risk exposure across lenders. The empirical results are very similar when we consider a battery of robustness tests.

Furthermore, we show that a foreign lender is more likely to take part in a syndicate if either i) there is a domestic national development bank as a participant lender and the lead bank is foreign or ii) there is a foreign (or global/regional) development bank as a participant lender. In contrast, we find that a domestic lender is more likely to take part in a syndicate if either i) there is a domestic national development bank as a participant lender or ii) there is a foreign (or multilateral) development bank as a participant lender and the lead bank is not a foreign lender.

Finally, we do not find evidence that development banks’ presence in syndicates is associated with a weaker monitoring outcome, such as higher probability of covenant violations. 


\section{References}

Ades, A., Di Tella, R. (1997). National champions and corruption: some unpleasant interventionist arithmetic. The Economic Journal, 107, 1023-1042.

Arezki, R., Bolton, P., Peters, S., Samama, F., Stiglitz, J. (2017). From Global Savings Glut to Financing Infrastructure. Economic Policy, 32(90), 221-261.

Bharath, S. Dahiya, S., Saunders, A., Srinivasan, A. (2011). Lending Relationships and Loan Contract Terms. Review of Financial Studies, 24 (4), 1141-1203.

Broccolini, C., Lotti, G., Maffioli, A., Presbitero, A.F., Stucchi, R (2019). Mobilization Effects of Multilateral Development Banks. World Bank Economic Review, Forthcoming.

Cen, L., Dasgupta, S., Elkamhi, R., Pungaliya, R. (2016). Reputation and Loan Contract Terms: the role of Principal Customers. Review of Finance. 20 (2), 501-533.

Chakraborty, I., Goldstein, I., Mackinlay, A. (2018). Do Asset Price Bubbles have Negative Real Effects? The Review of Financial Studies, 31(7), 2806-2853.

Chava, S., and Jarrow, R.A. (2004). Bankruptcy Prediction with Industry Effects. Review of Finance, 8, 537-569.

Chelsky, J., Morel, C., Kabir, M. (2013). Investment financing in the wake of the crisis: The role of multilateral development banks. World Bank - Economic Premise, 121.

Claessens, S., van Horen, N. (2014). Foreign banks: Trends and impact. Journal of Money, Credit and Banking, 46, 295-326.

Correia, S., Guimarães, P., \& Zylkin, T. (2020). Fast poisson estimation with high-dimensional fixed effects. The Stata Journal, 20(1), 95-115.

De Luna-Martinez, J., Vicente, C. (2012). Global Survey of Development Banks. World Bank Policy Research Working Paper. World Bank, Washington, DC, p. 5969.

Delis, M.D., Iosifidi, M., Kokas, S., Xefteris, D., Ongena, S. (2020). Enforcement actions on banks and the structure of loan syndicates. Journal of Corporate Finance, 60, 101527.

Demiroglu, C., James, C. (2010). The Information Content of Bank Loan Covenants. Review of Financial Studies, 23, 3700-3737.

Dennis, S.A., Mullineaux, D.J. (2000). Syndicated loans. Journal of Financial Intermediation, 9, 404426.

Dinc, I.S. (2005). Politicians and banks: Political influences on government-owned banks in emerging markets. Journal of Financial Economics, 77(2), 453-479.

Esty, B. (2004). When do foreign banks finance domestic projects? New evidence on the importance of legal and financial systems. Mimeo. Harvard Business School, Boston, MA. 
Esty, B., Megginson, W. (2003). Creditor rights, enforcement, and debt ownership structure: evidence from the global syndicated loan market. Journal of Financial and Quantitative Analysis, 38, 37-59.

Faccio, M. (2006). Politically connected firms. American Economic Review, 96, 369-386.

Frigerio, M., Vandone, D. (2020). European development banks and the political cycle. European Journal of Political Economy, 62.

Galindo, A. J., Panizza, U. (2018). The cyclicality of international public sector borrowing in developing countries: Does the lender matter? World Development, 112, 119-135.

Garcia-Appendini, E., Montoriol-Garriga, J. (2013). Firms as liquidity providers: Evidence from the 2007-2008 financial crisis. Journal of Financial Economics, 109, 272-291.

Gopalan, R., Nanda, V., Yerramilli, V. (2011). Does poor performance damage the reputation of financial intermediaries? Evidence from the loan syndication market. Journal of Finance, 66, 2083-2120.

Gurara, D., Presbitero, A. F., and Sarmiento, M. (2020). Borrowing costs and the role of multilateral development banks: Evidence from cross-border syndicated bank lending. Journal of International Money and Finance, 100, 1-17.

Hainz, C., Kleimeier, S. (2012). Political risk, project finance, and the participation of development banks in syndicated lending. Journal of Financial Intermediation, 21(2), 287-314.

Haselmann, R., Wachtel, P. (2011). Foreign banks in syndicated loan markets. Journal of Banking \& Finance, 35 (10), 2679-2689.

Humphrey, C., Michaelowa, K. (2013). Shopping for Development: Multilateral Lending, Shareholder Composition and Borrower Preferences. World Development, 44, 142-155.

Ivashina, V. (2009). Asymmetric information effects on loan spreads. Journal of Financial Economics, 92,300-319.

La Porta, R., Lopez-de-Silanes, F., Shleifer, A. (2002). Government ownership of banks. The Journal of Finance, 57(1), 265-301.

Lazzarini, S., Musacchio, A., Bandeire-De-Mello, R., Marcon, R. (2015). What do state-owned development banks do? Evidence from BNDES, 2002-2009. World Development, 66, 237-253.

Lee, S.W., Mullineaux, D.J. (2004) Monitoring, financial distress, and the structure of commercial lending syndicates, Financial Management, 33, 107-130.

Lin, C., Ma, Y., Malatesta, P., Xuan, Y. (2012). Corporate ownership structure and bank loan syndicate structure. Journal of Financial Economics, 104, 1-22.

Mazzucato, M., Penna, C.C.R. (2016). Beyond market failures: the market creating and shaping roles of state investment banks. Journal of Economic Policy Reform,19 (4), 305-326. 
Mian, A. (2006). Distance constraints: The limits of foreign lending in poor economies. Journal of Finance, 61, 1465-1505.

OECD (2018), Making Blended Finance Work for the Sustainable Development Goals, OECD Publishing, Paris. http://dx.doi.org/10.1787/9789264288768-en.

Sapienza, P. (2004). The effects of government ownership on bank lending. Journal of Financial Economics, 72(2), 357-384.

Sufi, A. (2007). Information asymmetry and financing arrangements: Evidence from syndicated loans. Journal of Finance, 62(2), 629-6.

Stein, J. (2002). Information production and capital allocation: decentra- lized versus hierarchical firms. Journal of Finance, 57, 1891-1922.

Xu, J., Ren, X. and Wu, X. (2019). Mapping Development Finance Institutions Worldwide: Definitions, Rationales, and Varieties. NSE Development Financing Research Report,1. DOI: 10.13140/RG.2.2.31323.62240. 
Table 1: Development banks in the syndicated loans

This table presents the percentage weight of development banks in the syndicated loans' market per macro-region by considering the borrower's country. The percentage weight is obtained both in terms of the number of loans (\# Loans) and of the deal amounts (Deal Amts). For each loan participated by at least one development bank, the deal amount refers to the whole deal and not only to the share participated by the development bank. The reference period is 20012016. Multinational development banks (MDBs) include global-level and regional-level development banks, while national development banks (NDBs) include national-level and sub-national level development banks.

\begin{tabular}{|c|c|c|c|c|c|c|c|}
\hline & \multirow[b]{2}{*}{ Obs. } & \multicolumn{2}{|c|}{$\begin{array}{l}\text { Percentage weight } \\
\text { (per cent) of DBs } \\
\text { in terms of: }\end{array}$} & \multicolumn{2}{|c|}{$\begin{array}{l}\text { Percentage weight } \\
\text { (per cent) of MDBs in } \\
\text { terms of: }\end{array}$} & \multicolumn{2}{|c|}{$\begin{array}{c}\text { Percentage weight } \\
\text { (per cent) of NDBs in } \\
\text { terms of: }\end{array}$} \\
\hline & & \# Loans & Amounts & \# Loans & Amounts & \# Loans & Amounts \\
\hline \multicolumn{8}{|l|}{ Macro-regions: } \\
\hline North America & 24,741 & 2.4 & 4.6 & 0.0 & 0.0 & 2.3 & 4.6 \\
\hline South America & 766 & 30.0 & 35.8 & 7.6 & 8.8 & 22.5 & 27.0 \\
\hline Western Europe & 4,690 & 9.9 & 17.2 & 0.5 & 0.6 & 9.4 & 16.6 \\
\hline Eastern Europe & 373 & 21.7 & 21.8 & 8.3 & 3.2 & 13.4 & 18.5 \\
\hline Africa & 132 & 15.9 & 10.5 & 6.1 & 3.5 & 9.8 & 7.0 \\
\hline Middle East & 138 & 15.2 & 15.8 & 2.9 & 4.1 & 12.3 & 11.7 \\
\hline Far East and Central Asia & 13,439 & 6.3 & 14.4 & 0.1 & 0.1 & 6.1 & 14.3 \\
\hline Oceania & 620 & 4.8 & 8.2 & 0.0 & 0.0 & 4.8 & 8.2 \\
\hline \multicolumn{8}{|l|}{ Industries (SIC divisions): } \\
\hline Agric., Forestry \& Fishing & 213 & 6.6 & 3.9 & 3.3 & 1.3 & 3.3 & 2.5 \\
\hline Mining & 3,704 & 9.1 & 17.4 & 0.8 & 1.3 & 8.3 & 16.1 \\
\hline Construction & 1,450 & 4.7 & 13.2 & 0.2 & 0.1 & 4.5 & 13.2 \\
\hline Manufacturing & 18,787 & 4.9 & 8.6 & 0.3 & 0.2 & 4.6 & 8.4 \\
\hline Transp., Communic., Elect & 8,468 & 8.3 & 12.7 & 0.5 & 0.4 & 7.8 & 12.3 \\
\hline Wholesale Trade & 2,502 & 3.0 & 4.8 & 0.2 & 0.2 & 2.9 & 4.6 \\
\hline Retail Trade & 3,164 & 1.3 & 1.7 & 0.1 & 0.0 & 1.2 & 1.7 \\
\hline Services & 6,611 & 1.6 & 3.5 & 0.0 & 0.0 & 1.6 & 3.5 \\
\hline \multicolumn{8}{|l|}{ Lead bank's nationality: } \\
\hline Same country as borrower & 35,659 & 3.5 & 6.4 & 0.1 & 0.0 & 3.4 & 6.4 \\
\hline Different country (cross-lending) & 9,240 & 11.3 & 15.6 & 1.4 & 1.0 & 9.9 & 14.6 \\
\hline \multicolumn{8}{|l|}{ Loan purposes: } \\
\hline Corporate purposes & 20,006 & 4.16 & 8.41 & 0.20 & 0.11 & 3.96 & 8.30 \\
\hline Working capital & 9,931 & 1.85 & 2.88 & 0.09 & 0.07 & 1.76 & 2.82 \\
\hline Debt Repayment & 4,891 & 7.83 & 18.61 & 0.35 & 0.30 & 7.48 & 18.31 \\
\hline Acquisition line & 1,719 & 5.24 & 8.51 & 0.12 & 1.19 & 5.12 & 7.32 \\
\hline Takeover & 1,711 & 3.68 & 7.88 & 0.23 & 0.54 & 3.45 & 7.34 \\
\hline Capital expenditure & 1,226 & 16.48 & 30.31 & 0.73 & 0.58 & 15.74 & 29.72 \\
\hline Project finance & 679 & 31.66 & 44.46 & 4.42 & 3.86 & 27.25 & 40.60 \\
\hline Other & 4,736 & 6.40 & 7.06 & 0.72 & 0.51 & 5.68 & 6.54 \\
\hline Total & 44,899 & 5.1 & 9.4 & 0.3 & 0.3 & 4.7 & 9.0 \\
\hline
\end{tabular}


Table 2: Loans participated in by at least one development bank: distribution by macro-region

Frequencies and amounts by region:

\begin{tabular}{lrr|rr}
\hline Macro-region & $\begin{array}{r}\text { \# Deals } \\
\text { (units) }\end{array}$ & percent & $\begin{array}{r}\text { Amounts } \\
\text { (billions US\$) }\end{array}$ & per cent \\
\hline North America & 586 & 25.8 & 749.6 & 29.6 \\
South America & 230 & 10.1 & 142.7 & 5.6 \\
Western Europe & 464 & 20.4 & $1,068.9$ & 42.3 \\
Eastern Europe & 81 & 3.6 & 52.6 & 2.1 \\
Africa & 21 & 0.9 & 23.8 & 0.3 \\
Middle East & 21 & 0.9 & 0.9 \\
Far East and Central Asia & 840 & 37.0 & 1.3 & 18.0 \\
Oceania & 30 & 100.0 & 29.1 & 1.2 \\
Total & 2,273 & & $2,529.6$ & 100.0
\end{tabular}


Table 3: Descriptive statistics for loans with and without development banks (Whole Sample)

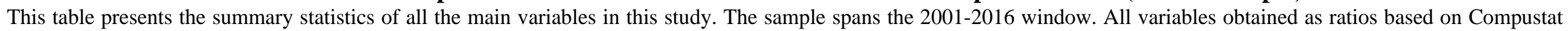
data are winsorized within the $1^{\text {st }}$ and $99^{\text {th }}$ percentiles. See Table 4 for variable definitions. Deals with a development banks as the lead bank are excluded from the analysis. T

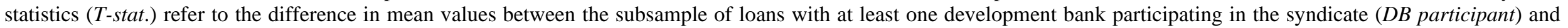
the subsample of loans with no DBs participating (No DBs). ***, **, and * denote statistical significance at the $1 \%$, $5 \%$, and $10 \%$ levels, respectively.

\begin{tabular}{|c|c|c|c|c|c|c|c|c|c|}
\hline \multirow[b]{2}{*}{ Variable } & \multicolumn{6}{|c|}{ Whole Sample } & \multirow{2}{*}{$\begin{array}{r}\text { No DBs } \\
\text { Mean } \\
\end{array}$} & \multirow{2}{*}{$\begin{array}{r}\text { DB Participant } \\
\text { Mean } \\
\end{array}$} & \multirow[t]{2}{*}{ T-stat. } \\
\hline & \#Obs. & Mean & St. Dev. & p25 & Median & p75 & & & \\
\hline \multicolumn{10}{|l|}{ Syndicate Characteristics: } \\
\hline Lead Share (per cent kept by the lead bank) & 13,679 & 28.55 & 23.78 & 10.67 & 20.69 & 40.00 & 29.15 & 18.86 & $-11.97^{* * *}$ \\
\hline Syndicate size (number of lenders) & 44,525 & 7.73 & 7.44 & 3.00 & 6.00 & 10.00 & 7.44 & 14.28 & $39.92^{* * *}$ \\
\hline Concentration of syndicate (Herfindahl) & 13,679 & 0.27 & 0.23 & 0.10 & 0.18 & 0.35 & 0.27 & 0.22 & $-5.81^{* * *}$ \\
\hline Number of foreign participant lenders & 44,525 & 2.59 & 4.58 & 0.00 & 1.00 & 3.00 & 2.35 & 8.10 & $55.40^{* * *}$ \\
\hline Foreign Share (per cent held by foreign lenders) & 13,679 & 22.56 & 27.98 & 0.00 & 9.04 & 40.32 & 21.17 & 44.78 & $23.68^{* * *}$ \\
\hline Deal amount (ln) & 44,524 & 19.11 & 1.53 & 18.09 & 19.11 & 20.18 & 19.07 & 19.99 & $25.89^{* * *}$ \\
\hline Deal maturity (months) & 43,697 & 47.86 & 34.05 & 24.00 & 49.00 & 60.00 & 46.99 & 67.33 & $25.45^{* * *}$ \\
\hline Collateral (dummy) & 44,525 & 0.33 & 0.47 & 0.00 & 0.00 & 1.00 & 0.33 & 0.27 & $-5.60^{* * *}$ \\
\hline Covenant (dummy) & 44,525 & 0.24 & 0.43 & 0.00 & 0.00 & 0.00 & 0.25 & 0.06 & $-18.48^{* * *}$ \\
\hline Institutional investors (dummy) & 44,525 & 0.23 & 0.42 & 0.00 & 0.00 & 0.00 & 0.23 & 0.24 & 0.09 \\
\hline Reputation: lead to participant & 44,525 & 0.30 & 0.19 & 0.14 & 0.32 & 0.43 & 0.30 & 0.35 & $11.42^{* * *}$ \\
\hline Reputation: reciprocal (dummy) & 44,525 & 0.88 & 0.33 & 1.00 & 1.00 & 1.00 & 0.88 & 0.96 & $11.06^{* * *}$ \\
\hline >1 loan tranche (dummy) & 44,525 & 0.30 & 0.46 & 0.00 & 0.00 & 1.00 & 0.29 & 0.43 & $13.08^{* * *}$ \\
\hline Deal includes term loan (dummy) & 44,525 & 0.43 & 0.50 & 0.00 & 0.00 & 1.00 & 0.42 & 0.61 & $16.59^{* * *}$ \\
\hline \multicolumn{10}{|l|}{ Borrower Characteristics: } \\
\hline Private firm (dummy) & 44,525 & 0.31 & 0.46 & 0.00 & 0.00 & 1.00 & 0.31 & 0.30 & -0.71 \\
\hline Total assets (ln) & 44,114 & 7.57 & 1.91 & 6.24 & 7.49 & 8.90 & 7.53 & 8.57 & $23.41^{* * *}$ \\
\hline ROA & 44,074 & 2.17 & 8.88 & 0.58 & 2.93 & 5.90 & 2.15 & 2.57 & $2.03^{*}$ \\
\hline Leverage & 44,112 & 31.72 & 20.40 & 17.40 & 29.88 & 43.14 & 31.63 & 33.82 & $4.58^{* * *}$ \\
\hline Tangibility & 43,987 & 35.72 & 24.87 & 14.85 & 31.00 & 53.77 & 35.26 & 45.92 & $18.29^{* * *}$ \\
\hline \multicolumn{10}{|l|}{ Lead bank Characteristics: } \\
\hline Big lead bank (dummy) & 44,525 & 0.35 & 0.48 & 0.00 & 0.00 & 1.00 & 0.36 & 0.20 & $-14.02^{* * *}$ \\
\hline Listed lead bank (dummy) & 44,525 & 0.53 & 0.50 & 0.00 & 1.00 & 1.00 & 0.54 & 0.39 & $-12.40^{* * *}$ \\
\hline \multicolumn{10}{|l|}{ Country Characteristics: } \\
\hline log GDP per capita & 43,045 & 10.53 & 0.65 & 10.54 & 10.65 & 10.79 & 10.56 & 9.85 & $-47.17^{* * *}$ \\
\hline Domestic credit to GDP (per cent) & 41,282 & 75.64 & 31.85 & 51.08 & 57.16 & 100.03 & 75.33 & 83.80 & $10.17^{* * *}$ \\
\hline
\end{tabular}


Table 4: Variables' Definitions

\begin{tabular}{|c|c|c|}
\hline Variable & Source & Description \\
\hline \multicolumn{3}{|r|}{ General } \\
\hline Lead bank & Dealscan & $\begin{array}{l}\text { The lead bank is identified by the highest ranked agent for each } \\
\text { loan following the ranking hierarchy suggested by Chakraborty et } \\
\text { al. (2018). }\end{array}$ \\
\hline $\begin{array}{c}\text { DB participant } \\
\text { (Participation of a DB) }\end{array}$ & Dealscan & $\begin{array}{l}\text { Dummy equal to one if at least one development bank is among the } \\
\text { participants (excluding the lead bank) in the loan syndicate. }\end{array}$ \\
\hline $\begin{array}{l}\text { Participation of a domestic } \\
\text { DB }\end{array}$ & Dealscan & $\begin{array}{l}\text { Dummy equal to one if the participants (excluding the lead bank) in } \\
\text { the loan syndicate include at least one national (or sub-national) } \\
\text { development bank that is in the same country as the borrowing } \\
\text { firm. }\end{array}$ \\
\hline $\begin{array}{l}\text { Participation of a foreign } \\
\text { DB }\end{array}$ & Dealscan & $\begin{array}{l}\text { Dummy equal to one if the participants (excluding the lead bank) in } \\
\text { the loan syndicate include either at least one multilateral (global or } \\
\text { regional) development bank, or at least one national (or sub- } \\
\text { national) development bank that is not in the same country as the } \\
\text { borrowing firm. }\end{array}$ \\
\hline \multicolumn{3}{|r|}{ Syndicate structure } \\
\hline $\begin{array}{c}\text { Syndicate size } \\
\text { (number of lenders) }\end{array}$ & Dealscan & Number of lenders participating in the lending syndicate. \\
\hline $\begin{array}{l}\text { Number of foreign } \\
\text { participant lenders }\end{array}$ & Dealscan & $\begin{array}{l}\text { Number of participant lenders of a syndicated loan that are not in } \\
\text { the same country as the borrowing firm. }\end{array}$ \\
\hline $\begin{array}{l}\text { Foreign Share } \\
\text { (per cent held by foreign } \\
\text { lenders) }\end{array}$ & Dealscan & Percentage held by foreign lenders of a syndicated loan. \\
\hline $\begin{array}{l}\text { Concentration of syndicate } \\
\text { (Herfindahl) }\end{array}$ & Dealscan & $\begin{array}{l}\text { Following Sufi (2007), the Herfindahl measures the concentration } \\
\text { of holdings within a syndicate by using each syndicate member's } \\
\text { share in the loan; it is the sum of the squared individual shares in } \\
\text { the loan (ranging from } 0 \text { to } 1 \text {, with } 1 \text { being the Herfindahl when a } \\
\text { lender holds } 100 \% \text { of the loan). }\end{array}$ \\
\hline $\begin{array}{l}\text { Lead Share } \\
\text { (per cent kept by the lead } \\
\text { bank) }\end{array}$ & Dealscan & $\begin{array}{l}\text { Following Sufi (2007), percentage retained by the lead bank of a } \\
\text { syndicated loan. }\end{array}$ \\
\hline \multicolumn{3}{|r|}{ Other loan characteristics } \\
\hline Loan amount (ln) & Dealscan & $\begin{array}{l}\text { Natural logarithm of loan amount in USD million as indicated in } \\
\text { the field DealAmt in Dealscan. }\end{array}$ \\
\hline Loan maturity (months) & Dealscan & $\begin{array}{l}\text { Maturity (in months) of the largest facility within-loan package that } \\
\text { starts at the loan origination date. }\end{array}$ \\
\hline Collateral & Dealscan & Dummy equal to one if the loan is secured, and zero otherwise. \\
\hline Covenant & Dealscan & $\begin{array}{l}\text { Dummy equal to one if the loan has at least one financial covenant } \\
\text { (considering equity sweeps, debt sweeps, asset sweeps, dividend } \\
\text { restrictions, and secured debt), and zero otherwise. }\end{array}$ \\
\hline Institutional investors & Dealscan & $\begin{array}{l}\text { Dummy equal to one if at least one institutional investor is in the } \\
\text { loan syndicate. Institutional investors include all lenders labelled in } \\
\text { DealScan as 'institutional investor', 'finance company', 'insurance } \\
\text { company', 'mutual fund', or 'pension fund'. }\end{array}$ \\
\hline$>1$ loan tranche & Dealscan & $\begin{array}{l}\text { Dummy equal to one if the number of facilities in the loan package } \\
\text { is larger than one, and zero otherwise. }\end{array}$ \\
\hline Term loan & Dealscan & $\begin{array}{l}\text { Dummy equal to one if the loan package contains a term loan } \\
\text { facility, and zero otherwise. }\end{array}$ \\
\hline Loan purpose & Dealscan & $\begin{array}{l}\text { Purpose of the of the syndicated loan. Based on labeling in } \\
\text { DealScan, eight categories are considered: acquisition line; capital } \\
\text { expenditure; corporate purposes; debt repayment; project finance; } \\
\text { takeover; working capital; other. }\end{array}$ \\
\hline \multicolumn{3}{|r|}{ Syndicate reputation } \\
\hline Syndicate reputation: lead & Dealscan & Following Ivashina (2009), the maximum per cent number of deals \\
\hline
\end{tabular}




\begin{tabular}{|c|c|c|}
\hline to participant & & $\begin{array}{l}\text { arranged by the same lead bank with the same participants against } \\
\text { the total number of deals organized by the lead bank over a five- } \\
\text { year horizon. }\end{array}$ \\
\hline $\begin{array}{l}\text { Syndicate reputation: } \\
\text { reciprocal }\end{array}$ & Dealscan & $\begin{array}{l}\text { Following Ivashina (2009), dummy variable is equal to one if the } \\
\text { same lead bank and the same participant switch roles over a five- } \\
\text { year horizon prior to the current syndication. }\end{array}$ \\
\hline \multicolumn{3}{|r|}{ Borrower characteristics } \\
\hline Private firm & Compustat & $\begin{array}{l}\text { Dummy variable equal to one if the borrower is not a publicly } \\
\text { traded company. }\end{array}$ \\
\hline Total assets & Compustat & Total assets in US millions of dollars. \\
\hline Profitability (ROA) & Compustat & Ratio of net income to total assets. \\
\hline Leverage & Compustat & Ratio of book value of total debt to book value of assets. \\
\hline Tangibility & Compustat & $\begin{array}{l}\text { Ratio of tangible fixed assets (Net Property, Plant and Equipment) } \\
\text { to total assets. }\end{array}$ \\
\hline \multicolumn{3}{|c|}{ Development banks (DBs)' characteristics } \\
\hline $\begin{array}{l}\text { National (or sub-national) } \\
\text { DB }\end{array}$ & $\begin{array}{l}\text { Xu et al. } \\
\text { (2019) and } \\
\text { own additional } \\
\text { inspection }\end{array}$ & $\begin{array}{l}\text { Dummy variable equal to one if the development bank is } \\
\text { established by the central or local government of a single country, } \\
\text { and zero if established by two or more countries (i.e. multilateral } \\
\text { DBs), and zero otherwise. }\end{array}$ \\
\hline Global (or regional) DB & $\begin{array}{l}\text { Xu et al. } \\
\text { (2019) and } \\
\text { own additional } \\
\text { inspection }\end{array}$ & $\begin{array}{l}\text { Dummy variable equal to one if the development bank is either a } \\
\text { global or regional development bank, and zero if established by a } \\
\text { single country (i.e. national DBs), and zero otherwise. }\end{array}$ \\
\hline Domestic DB & $\begin{array}{l}\text { Xu et al. } \\
\text { (2019) and } \\
\text { own additional } \\
\text { inspection }\end{array}$ & $\begin{array}{l}\text { Dummy variable equal to one if the development bank has its } \\
\text { headquarters in the borrowing firm's country, and zero otherwise. }\end{array}$ \\
\hline Foreign DB & $\begin{array}{l}\text { Xu et al. } \\
\text { (2019) and } \\
\text { own additional } \\
\text { inspection }\end{array}$ & $\begin{array}{l}\text { Dummy variable equal to one if the development bank has its } \\
\text { headquarters in a different country with respect to the borrowing } \\
\text { firm's country, and zero otherwise. }\end{array}$ \\
\hline \multicolumn{3}{|c|}{ Lead bank characteristics } \\
\hline $\begin{array}{l}\text { The lead bank is a former } \\
\text { lender for borrower }\end{array}$ & Dealscan & $\begin{array}{l}\text { Dummy equal to one if the lead bank lent to the same borrower in } \\
\text { the past five years (as the participant lender in the syndicate), and } \\
\text { zero otherwise. }\end{array}$ \\
\hline $\begin{array}{l}\text { Lead bank is former lead } \\
\text { bank for borrower }\end{array}$ & Dealscan & $\begin{array}{l}\text { Dummy equal to one if the lead bank lent to the same borrower in } \\
\text { the past five years (as the lead bank in the syndicate), and zero } \\
\text { otherwise. }\end{array}$ \\
\hline The lead bank is foreign & Dealscan & $\begin{array}{l}\text { Dummy equal to one if the lead bank is not in the same country as } \\
\text { the borrowing firm, and zero otherwise. }\end{array}$ \\
\hline Big lead bank & DealScan & $\begin{array}{l}\text { Dummy variable equal to one if the lead bank is one of the five } \\
\text { lenders with the highest market share in the syndicated loans } \\
\text { market within the time period of the analysis (Bank of America } \\
\text { Merrill Lynch; Citi; Deutsche Bank AG; JP Morgan; Wells Fargo } \\
\text { \& Co) }\end{array}$ \\
\hline Listed lead bank & DealScan & $\begin{array}{l}\text { Dummy variable equal to one if the lead bank is a publicly traded } \\
\text { company, and zero otherwise. }\end{array}$ \\
\hline \multicolumn{3}{|c|}{ Characteristics of other lenders } \\
\hline The lender is foreign & Dealscan & $\begin{array}{l}\text { Dummy equal to one if the lender is not in the same country as the } \\
\text { borrowing firm, and zero otherwise. }\end{array}$ \\
\hline $\begin{array}{l}\text { 'Top' industry for the } \\
\text { lender }\end{array}$ & Dealscan & $\begin{array}{l}\text { Dummy equal to one if industry of the borrowing firm is the } \\
\text { industry (2-digit SIC) with the highest participation of lender } i \text { in } \\
\text { the last five years before the origination year } t \text { of the syndicated } \\
\text { loan } j \text {, and zero otherwise. }\end{array}$ \\
\hline ‘Top’ industry and country & Dealscan & $\begin{array}{l}\text { Dummy equal to one if industry and country of the borrowing firm } \\
\text { is the industry (2-digit SIC) and the country with the highest }\end{array}$ \\
\hline
\end{tabular}




\begin{tabular}{|c|c|c|}
\hline & & $\begin{array}{l}\text { participation of lender } i \text { in the last five years before the origination } \\
\text { year } t \text { of the syndicated loan } j \text {, and zero otherwise. }\end{array}$ \\
\hline $\begin{array}{l}\text { Lender former lead bank } \\
\text { for borrower }\end{array}$ & Dealscan & $\begin{array}{l}\text { Dummy equal to one if the lender lent to the same borrower in the } \\
\text { past five years (as lead bank), and zero otherwise. }\end{array}$ \\
\hline $\begin{array}{l}\text { Lender former participant } \\
\text { for borrower }\end{array}$ & Dealscan & $\begin{array}{l}\text { Dummy equal to one if the lender lent to the same borrower in the } \\
\text { past five years (as participant lender), and zero otherwise. }\end{array}$ \\
\hline $\begin{array}{c}\text { Lender on syndicate with } \\
\text { the lead bank in the last } \\
\text { five years }\end{array}$ & Dealscan & $\begin{array}{l}\text { Dummy variable equal to one if the lender has collaborated with the } \\
\text { lead bank (i.e. they have been in the same loan syndicate at least } \\
\text { once) in the past five years, and zero otherwise. }\end{array}$ \\
\hline \multicolumn{3}{|r|}{ Country characteristics } \\
\hline log GDP per capita & World Bank & $\begin{array}{l}\text { Logarithm of gross domestic product divided by midyear } \\
\text { population at the country-year level. }\end{array}$ \\
\hline $\begin{array}{l}\text { Domestic credit to GDP } \\
\text { (per cent) }\end{array}$ & World Bank & $\begin{array}{l}\text { Domestic credit to private sector as percentage of gross domestic } \\
\text { product at the country-year level. Domestic credit to private sector } \\
\text { refers to financial resources provided to the private sector by } \\
\text { financial corporations. }\end{array}$ \\
\hline
\end{tabular}


Table 5: Baseline results

This table reports the estimation results of the baseline model. Variable definitions are provided in Table 4. Standard errors clustered by borrower are reported in parentheses. ***, **, and * denote statistical significance at the $1 \%$, 5\%, and $10 \%$ levels, respectively.

\begin{tabular}{|c|c|c|c|c|c|}
\hline Dependent variable: & $\begin{array}{l}\text { Syndicate size } \\
\text { (number of } \\
\text { lenders) }\end{array}$ & $\begin{array}{l}\text { Lead Share } \\
\text { (per cent kept } \\
\text { by lead bank) }\end{array}$ & $\begin{array}{l}\text { Concentration } \\
\text { (Herfindahl) }\end{array}$ & $\begin{array}{l}\text { Number of } \\
\text { foreign } \\
\text { participant } \\
\text { lenders } \\
\end{array}$ & $\begin{array}{c}\text { Foreign Share } \\
\text { (per cent kept } \\
\text { by foreign } \\
\text { lenders) }\end{array}$ \\
\hline & $(1)$ & $(2)$ & (3) & $(4)$ & (5) \\
\hline DB participant & $\begin{array}{l}4.79^{* * * *} \\
{[0.40]}\end{array}$ & $\begin{array}{c}-2.87^{* * *} \\
{[0.89]}\end{array}$ & $\begin{array}{c}-0.03^{* * *} \\
{[0.01]}\end{array}$ & $\begin{array}{l}3.66^{* * *} \\
{[0.35]}\end{array}$ & $\begin{array}{l}5.20^{* * *} \\
{[1.09]}\end{array}$ \\
\hline The lead bank is a former lender & $\begin{array}{l}0.17^{* * *} \\
{[0.07]}\end{array}$ & $\begin{array}{l}-0.60 \\
{[0.42]}\end{array}$ & $\begin{array}{c}-0.01^{* * * *} \\
{[0.00]}\end{array}$ & $\begin{array}{c}-0.12^{* * * *} \\
{[0.04]}\end{array}$ & $\begin{array}{l}-0.62 \\
{[0.38]}\end{array}$ \\
\hline The lead bank is foreign & $\begin{array}{l}1.25^{* * *} \\
{[0.14]}\end{array}$ & $\begin{array}{c}-2.47^{* * * *} \\
{[0.72]}\end{array}$ & $\begin{array}{l}-0.01 \\
{[0.01]}\end{array}$ & $\begin{array}{l}1.91^{* * * *} \\
{[0.11]}\end{array}$ & $\begin{array}{c}17.46^{* * *} \\
{[1.00]}\end{array}$ \\
\hline Reputation: lead to participant & $\begin{array}{l}7.96^{* * * *} \\
{[0.27]}\end{array}$ & $\begin{array}{c}-22.13^{* * *} \\
{[1.77]}\end{array}$ & $\begin{array}{l}-0.30^{* * *} \\
{[0.02]}\end{array}$ & $\begin{array}{l}2.76^{* * * *} \\
{[0.16]}\end{array}$ & $\begin{array}{l}3.90^{* * *} \\
{[1.47]}\end{array}$ \\
\hline Reputation: reciprocal & $\begin{array}{l}0.49^{* * *} \\
{[0.11]}\end{array}$ & $\begin{array}{c}-22.61^{* * *} \\
{[1.38]}\end{array}$ & $\begin{array}{c}-0.26^{* * *} \\
{[0.01]}\end{array}$ & $\begin{array}{c}-0.52^{* * *} \\
{[0.07]}\end{array}$ & $\begin{array}{l}5.35^{* * *} \\
{[0.83]}\end{array}$ \\
\hline Private firm (dummy) & $\begin{array}{c}-0.42^{* * * *} \\
{[0.10]}\end{array}$ & $\begin{array}{l}-0.41 \\
{[0.50]}\end{array}$ & $\begin{array}{l}-0.01^{* *} \\
{[0.00]}\end{array}$ & $\begin{array}{c}-0.27^{* * * *} \\
{[0.06]}\end{array}$ & $\begin{array}{c}0.03 \\
{[0.48]}\end{array}$ \\
\hline Total assets (ln) & $\begin{array}{l}0.11^{* * * *} \\
{[0.03]}\end{array}$ & $\begin{array}{l}-0.33^{*} \\
{[0.18]}\end{array}$ & $\begin{array}{l}0.00^{* * *} \\
{[0.00]}\end{array}$ & $\begin{array}{l}0.18^{* * * *} \\
{[0.02]}\end{array}$ & $\begin{array}{l}1.46^{* * *} \\
{[0.18]}\end{array}$ \\
\hline ROA & $\begin{array}{l}0.01^{* * *} \\
{[0.00]}\end{array}$ & $\begin{array}{c}-0.08^{* * * *} \\
{[0.03]}\end{array}$ & $\begin{array}{c}-0.00^{* * * *} \\
{[0.00]}\end{array}$ & $\begin{array}{l}-0.00 \\
{[0.00]}\end{array}$ & $\begin{array}{c}-0.01 \\
{[0.02]}\end{array}$ \\
\hline Leverage & $\begin{array}{c}-0.00 \\
{[0.00]}\end{array}$ & $\begin{array}{c}-0.03^{* *} \\
{[0.01]}\end{array}$ & $\begin{array}{c}-0.00^{* *} \\
{[0.00]}\end{array}$ & $\begin{array}{c}-0.00^{* * * *} \\
{[0.00]}\end{array}$ & $\begin{array}{c}-0.01 \\
{[0.01]}\end{array}$ \\
\hline Tangibility & $\begin{array}{c}0.00 \\
{[0.00]}\end{array}$ & $\begin{array}{c}-0.03^{* * *} \\
{[0.01]}\end{array}$ & $\begin{array}{c}-0.00^{* * *} \\
{[0.00]}\end{array}$ & $\begin{array}{c}0.00 \\
{[0.00]}\end{array}$ & $\begin{array}{c}0.02 \\
{[0.01]}\end{array}$ \\
\hline Deal amount $(\ln )$ & $\begin{array}{l}1.78^{* * * *} \\
{[0.05]}\end{array}$ & $\begin{array}{c}-3.47^{* * *} \\
{[0.29]}\end{array}$ & $\begin{array}{c}-0.03^{* * *} \\
{[0.00]}\end{array}$ & $\begin{array}{l}0.92^{* * *} \\
{[0.03]}\end{array}$ & $\begin{array}{l}3.05^{* * *} \\
{[0.27]}\end{array}$ \\
\hline Deal maturity (months) & $\begin{array}{l}0.17^{* * * *} \\
{[0.06]}\end{array}$ & $\begin{array}{c}-3.51^{* * * *} \\
{[0.39]}\end{array}$ & $\begin{array}{c}-0.02^{* * * *} \\
{[0.00]}\end{array}$ & $\begin{array}{l}-0.05 \\
{[0.04]}\end{array}$ & $\begin{array}{c}0.08 \\
{[0.33]}\end{array}$ \\
\hline Collateral (dummy) & $\begin{array}{c}-1.42^{* * * *} \\
{[0.10]}\end{array}$ & $\begin{array}{l}4.78^{* * * *} \\
{[0.52]}\end{array}$ & $\begin{array}{l}0.05^{* * *} \\
{[0.01]}\end{array}$ & $\begin{array}{c}-0.89^{* * * *} \\
{[0.07]}\end{array}$ & $\begin{array}{c}-2.24^{* * * *} \\
{[0.56]}\end{array}$ \\
\hline Covenant (dummy) & $\begin{array}{l}0.98^{* * * *} \\
{[0.10]}\end{array}$ & $\begin{array}{l}1.68^{* * *} \\
{[0.50]}\end{array}$ & $\begin{array}{l}0.01^{* * *} \\
{[0.00]}\end{array}$ & $\begin{array}{c}-0.02 \\
{[0.06]}\end{array}$ & $\begin{array}{c}-4.48^{* * * *} \\
{[0.59]}\end{array}$ \\
\hline Institutional investors (dummy) & $\begin{array}{l}4.10^{* * * *} \\
{[0.12]}\end{array}$ & $\begin{array}{c}-6.80^{* * * *} \\
{[0.45]}\end{array}$ & $\begin{array}{c}-0.06^{* * *} \\
{[0.00]}\end{array}$ & $\begin{array}{l}1.36^{* * * *} \\
{[0.07]}\end{array}$ & $\begin{array}{c}0.80^{*} \\
{[0.44]}\end{array}$ \\
\hline$>1$ loan tranche (dummy) & $\begin{array}{l}0.37^{* * * *} \\
{[0.13]}\end{array}$ & $\begin{array}{c}0.97^{*} \\
{[0.54]}\end{array}$ & $\begin{array}{l}0.03^{* * *} \\
{[0.01]}\end{array}$ & $\begin{array}{l}0.37^{* * * *} \\
{[0.08]}\end{array}$ & $\begin{array}{l}-0.60 \\
{[0.54]}\end{array}$ \\
\hline Deal includes term loan (dummy) & $\begin{array}{c}0.06 \\
{[0.13]}\end{array}$ & $\begin{array}{l}-1.10^{*} \\
{[0.60]}\end{array}$ & $\begin{array}{c}0.01 \\
{[0.01]}\end{array}$ & $\begin{array}{c}-0.28^{* * * *} \\
{[0.07]}\end{array}$ & $\begin{array}{l}-0.12 \\
{[0.54]}\end{array}$ \\
\hline Domestic credit to GDP (per cent) & $\begin{array}{c}-0.01^{* *} \\
{[0.00]}\end{array}$ & $\begin{array}{l}0.05^{* *} \\
{[0.02]}\end{array}$ & $\begin{array}{l}0.00^{* * * *} \\
{[0.00]}\end{array}$ & $\begin{array}{c}-0.01^{* * * *} \\
{[0.00]}\end{array}$ & $\begin{array}{c}-0.07^{* *} \\
{[0.03]}\end{array}$ \\
\hline log GDP per capita & $\begin{array}{c}-1.46^{* * * *} \\
{[0.26]}\end{array}$ & $\begin{array}{c}2.77 \\
{[1.70]}\end{array}$ & $\begin{array}{c}0.02 \\
{[0.02]}\end{array}$ & $\begin{array}{c}-1.44^{* * * *} \\
{[0.24]}\end{array}$ & $\begin{array}{c}-7.91^{* * * *} \\
{[1.99]}\end{array}$ \\
\hline Loan purpose dummies & YES & YES & YES & YES & YES \\
\hline Lead bank effects & YES & YES & YES & YES & YES \\
\hline Country effects & YES & YES & YES & YES & YES \\
\hline Year effects & YES & YES & YES & YES & YES \\
\hline Industry (division) effects & YES & YES & YES & YES & YES \\
\hline $\begin{array}{l}\text { Observations } \\
\text { r2 }\end{array}$ & $\begin{array}{c}40,280 \\
0.43 \\
\end{array}$ & $\begin{array}{c}12,322 \\
0.46 \\
\end{array}$ & $\begin{array}{c}12,322 \\
0.48\end{array}$ & $\begin{array}{c}40,280 \\
0.50\end{array}$ & $\begin{array}{c}12,322 \\
0.63\end{array}$ \\
\hline
\end{tabular}


Table 6: (A) Domestic vs. foreign DBs; (B) National vs. Supranational DBs

This table reports the estimation results of the baseline model after excluding loans with no development banks (DBs) participating to the syndicate and distinguishing foreign DBs from domestic DBs, and national DBs form supranational DBs. DBs are defined as foreign when their origin country is different from the origin country of the borrower. Consequently, the coefficient on the Foreign DB dummy reveals how foreign DBs compare to domestic DBs, while the coefficient on the Global (or regional) DB dummy reveals how supranational DBs compare to national DBs. Variable definitions are provided in Table 4. Standard errors clustered by borrower are reported in parentheses. $* * *, * *$, and $*$ denote statistical significance at the $1 \%, 5 \%$, and $10 \%$ levels, respectively.

\begin{tabular}{|c|c|c|c|c|c|}
\hline Panel A: Dependent variable: & $\begin{array}{l}\text { Syndicate size } \\
\text { (number of } \\
\text { lenders) }\end{array}$ & $\begin{array}{l}\text { Lead Share } \\
\text { (per cent kept } \\
\text { by lead bank) }\end{array}$ & $\begin{array}{c}\text { Concentration } \\
\text { (Herfindahl) }\end{array}$ & $\begin{array}{l}\text { Number of } \\
\text { foreign } \\
\text { participant } \\
\text { lenders }\end{array}$ & $\begin{array}{c}\text { Foreign Share } \\
\text { (per cent kept } \\
\text { by foreign } \\
\text { lenders }\end{array}$ \\
\hline & (1a) & $(2 a)$ & (3a) & $(4 a)$ & $(5 a)$ \\
\hline Participation of a domestic DB & (ref.) & (ref.) & (ref.) & (ref.) & (ref.) \\
\hline Participation of a foreign DB & $\begin{array}{c}1.28 \\
{[0.84]}\end{array}$ & $\begin{array}{c}1.35 \\
{[3.18]}\end{array}$ & $\begin{array}{l}-0.05 \\
{[0.04]}\end{array}$ & $\begin{array}{c}2.54 * * * \\
{[0.74]}\end{array}$ & $\begin{array}{c}28.57 * * * \\
{[4.11]}\end{array}$ \\
\hline The lead bank is a former lender & $\begin{array}{l}1.13^{* *} \\
{[0.53]}\end{array}$ & $\begin{array}{c}2.11 \\
{[1.91]}\end{array}$ & $\begin{array}{c}0.01 \\
{[0.02]}\end{array}$ & $\begin{array}{c}0.39 \\
{[0.40]}\end{array}$ & $\begin{array}{l}-0.10 \\
{[1.89]}\end{array}$ \\
\hline The lead bank is foreign & $\begin{array}{l}1.67 * * \\
{[0.72]}\end{array}$ & $\begin{array}{l}-0.95 \\
{[2.53]}\end{array}$ & $\begin{array}{c}0.01 \\
{[0.03]}\end{array}$ & $\begin{array}{c}3.51 * * * \\
{[0.67]}\end{array}$ & $\begin{array}{c}17.48 * * * \\
{[3.41]}\end{array}$ \\
\hline Reputation: lead to participant & $\begin{array}{c}10.65^{* * *} \\
{[2.04]}\end{array}$ & $\begin{array}{c}-13.43^{*} \\
{[7.38]}\end{array}$ & $\begin{array}{c}-0.31 * * * \\
{[0.08]}\end{array}$ & $\begin{array}{c}6.63 * * * \\
{[1.47]}\end{array}$ & $\begin{array}{l}11.32 \\
{[8.30]}\end{array}$ \\
\hline Reputation: reciprocal & $\begin{array}{c}1.05 \\
{[0.98]}\end{array}$ & $\begin{array}{c}0.48 \\
{[6.01]}\end{array}$ & $\begin{array}{l}-0.06 \\
{[0.05]}\end{array}$ & $\begin{array}{l}-0.30 \\
{[0.94]}\end{array}$ & $\begin{array}{c}13.97 * * * \\
{[4.48]}\end{array}$ \\
\hline Borrower characteristics & YES & YES & YES & YES & YES \\
\hline Syndicate characteristics & YES & YES & YES & YES & YES \\
\hline Country-year characteristics & YES & YES & YES & YES & YES \\
\hline Loan purpose dummies & YES & YES & YES & YES & YES \\
\hline Lead bank effects & YES & YES & YES & YES & YES \\
\hline Country effects & YES & YES & YES & YES & YES \\
\hline Year effects & YES & YES & YES & YES & YES \\
\hline Industry (division) effects & YES & YES & YES & YES & YES \\
\hline $\begin{array}{c}\text { Observations } \\
\text { r2 }\end{array}$ & $\begin{array}{c}1,569 \\
0.64\end{array}$ & $\begin{array}{l}755 \\
0.53\end{array}$ & $\begin{array}{l}755 \\
0.62\end{array}$ & $\begin{array}{c}1,569 \\
0.70\end{array}$ & $\begin{array}{l}755 \\
0.62\end{array}$ \\
\hline Panel B & (1b) & (2b) & (3b) & (4b) & (5b) \\
\hline National (or sub-national) DB & (ref.) & (ref.) & (ref.) & (ref.) & (ref.) \\
\hline Global (or regional) DB & $\begin{array}{c}0.70 \\
{[1.10]}\end{array}$ & $\begin{array}{c}-10.66^{* *} \\
{[4.31]}\end{array}$ & $\begin{array}{c}0.08 \\
{[0.05]}\end{array}$ & $\begin{array}{c}0.79 \\
{[1.03]}\end{array}$ & $\begin{array}{c}13.70 * * \\
{[6.04]}\end{array}$ \\
\hline The lead bank is a former lender & $\begin{array}{l}1.11^{* *} \\
{[0.53]}\end{array}$ & $\begin{array}{c}2.21 \\
{[1.92]}\end{array}$ & $\begin{array}{c}0.01 \\
{[0.02]}\end{array}$ & $\begin{array}{c}0.36 \\
{[0.40]}\end{array}$ & $\begin{array}{l}-1.13 \\
{[2.02]}\end{array}$ \\
\hline The lead bank is foreign & $\begin{array}{l}1.84^{* *} \\
{[0.72]}\end{array}$ & $\begin{array}{l}-0.83 \\
{[2.54]}\end{array}$ & $\begin{array}{c}0.01 \\
{[0.03]}\end{array}$ & $\begin{array}{c}3.85^{* * * *} \\
{[0.69]}\end{array}$ & $\begin{array}{c}21.68 * * * \\
{[3.59]}\end{array}$ \\
\hline Reputation: lead to participant & $\begin{array}{c}10.76 * * * \\
{[2.06]}\end{array}$ & $\begin{array}{c}-13.32 * \\
{[7.26]}\end{array}$ & $\begin{array}{c}-0.31 * * * \\
{[0.08]}\end{array}$ & $\begin{array}{c}6.86 * * * \\
{[1.49]}\end{array}$ & $\begin{array}{l}14.72^{*} \\
{[8.73]}\end{array}$ \\
\hline Reputation: reciprocal & $\begin{array}{c}1.12 \\
{[0.98]}\end{array}$ & $\begin{array}{c}1.28 \\
{[5.90]}\end{array}$ & $\begin{array}{l}-0.07 \\
{[0.05]}\end{array}$ & $\begin{array}{l}-0.12 \\
{[0.96]}\end{array}$ & $\begin{array}{c}17.77 * * * \\
{[5.60]}\end{array}$ \\
\hline Borrower characteristics & YES & YES & YES & YES & YES \\
\hline Syndicate characteristics & YES & YES & YES & YES & YES \\
\hline Country-year characteristics & YES & YES & YES & YES & YES \\
\hline Loan purpose dummies & YES & YES & YES & YES & YES \\
\hline Lead bank effects & YES & YES & YES & YES & YES \\
\hline Country effects & YES & YES & YES & YES & YES \\
\hline Year effects & YES & YES & YES & YES & YES \\
\hline Industry (division) effects & YES & YES & YES & YES & YES \\
\hline $\begin{array}{c}\text { Observations } \\
\text { r2 }\end{array}$ & $\begin{array}{c}1,569 \\
0.64\end{array}$ & $\begin{array}{l}755 \\
0.53 \\
\end{array}$ & $\begin{array}{l}755 \\
0.62 \\
\end{array}$ & $\begin{array}{c}1,569 \\
0.70\end{array}$ & $\begin{array}{l}755 \\
0.78 \\
\end{array}$ \\
\hline
\end{tabular}


Table 7: Baseline results with matching procedure

This table reports the estimation results of the baseline model with matching procedure. Variable definitions are provided in Table 4 . Standard errors clustered by borrower are reported in parentheses. ${ }^{* * *}$, **, and $*$ denote statistical significance at the $1 \%, 5 \%$, and $10 \%$ levels, respectively.

\begin{tabular}{lc|c|c|c|c}
\hline & $\begin{array}{c}\text { Syndicate size } \\
\text { (number of } \\
\text { lenders) }\end{array}$ & $\begin{array}{c}\text { Lead Share } \\
\text { (per cent kept } \\
\text { by lead bank) }\end{array}$ & $\begin{array}{c}\text { Concentration } \\
\text { (Herfindahl) }\end{array}$ & $\begin{array}{c}\text { Number of } \\
\text { foreign } \\
\text { participant } \\
\text { lenders }\end{array}$ & $\begin{array}{c}\text { Foreign Share } \\
\text { (per cent kept } \\
\text { by foreign } \\
\text { lenders }\end{array}$ \\
\hline DB participant & $(1)$ & $(2)$ & $(3)$ & $(4)$ & $(5)$ \\
& $4.22^{* * *}$ & $-3.90^{* * *}$ & $-0.04^{* * *}$ & $2.96^{* * *}$ & $4.57^{* * *}$ \\
The lead bank is a former lender & {$[0.39]$} & {$[1.24]$} & {$[0.01]$} & {$[0.28]$} & -0.29 \\
& -0.10 & 1.46 & 0.01 & -0.48 \\
The lead bank is foreign & {$[0.25]$} & {$[1.24]$} & {$[0.01]$} & {$[0.19]$} & {$[1.14]$} \\
Reputation: lead to participant & $1.57^{* * *}$ & -1.94 & 0.00 & $2.96^{* * *}$ & $22.67^{* * *}$ \\
Reputation: reciprocal & {$[0.36]$} & {$[1.42]$} & {$[0.02]$} & {$[0.33]$} & {$[2.19]$} \\
& $10.94^{* * *}$ & $-21.02^{* * *}$ & $-0.32^{* * *}$ & $6.21^{* * *}$ & $10.62^{* * *}$ \\
\hline Borrower characteristics & {$[0.86]$} & {$[4.14]$} & {$[0.04]$} & {$[0.60]$} & {$[3.98]$} \\
Syndicate characteristics & 0.39 & $-5.59^{*}$ & $-0.11^{* * *}$ & $-0.85^{* * *}$ & $8.50^{* * *}$ \\
Country-year characteristics & {$[0.36]$} & {$[3.23]$} & {$[0.03]$} & {$[0.30]$} & {$[2.56]$} \\
Loan purpose dummies & YES & YES & YES & YES & YES \\
Lead bank effects & YES & YES & YES & YES & YES \\
Country effects & YES & YES & YES & YES & YES \\
Year effects & YES & YES & YES & YES & YES \\
Industry (division) effects & YES & YES & YES & YES & YES \\
\hline Observations & YES & YES & YES & YES & YES \\
r2 & YES & YES & YES & YES & YES \\
\hline
\end{tabular}


Table 8: The determinants of relevant lenders' participation in a syndicate

This table reports the coefficient estimates for a linear probability model (LPM) specification estimating how lender and loan characteristics affect the probability of a lender being chosen as a participant. All coefficients and standard errors are multiplied by 100 . Columns 1,3 and 5 include loan purpose, country, year and industry effects, while Columns 2, 4 and 6 also encompass borrower, syndicate, lead bank, lender and country-year characteristics. Columns 1 and 2 refer to the entire sample of potential lenders, Columns 3 and 4 consider only potential domestic lenders, while Columns 5 and 6 consider only foreign lenders. For each loan (package) the choice set includes all relevant lenders with at least $0.5 \%$ market share in at least one country in the year of the loan. All the estimations include country, year and industry (SIC division) effects and an additional set of dummies for loan purposes. Additional controls (Columns 3 and 4) include borrower characteristics in year $t-1$ and deal characteristics. In Column 4, we also control for lender characteristics and country-year characteristics. The "domestic" vs. "foreign" nationality of DBs and lead banks is assigned based on the borrower's country. Variable definitions are provided in Table 4. Standard errors (in brackets) are allowed to be correlated for all potential participant development banks for all of a given firm's loans in the sample. In addition to the variables reported, All coefficients and standard errors are multiplied by 100 .

\begin{tabular}{|c|c|c|c|c|c|c|}
\hline \multicolumn{7}{|c|}{ Dependent variable: Probability of a potential lender being chosen as a participant } \\
\hline & \multicolumn{2}{|c|}{$\begin{array}{l}\text { Potential } \\
\text { Lenders }\end{array}$} & \multicolumn{2}{|c|}{$\begin{array}{c}\text { Potential } \\
\text { domestic lenders }\end{array}$} & \multicolumn{2}{|c|}{$\begin{array}{c}\text { Potential } \\
\text { foreign lenders }\end{array}$} \\
\hline & $(1)$ & (2) & (3) & $(4)$ & (5) & (6) \\
\hline Dependent variable mean & 6.41 & 7.30 & 22.68 & 23.51 & 4.03 & 4.50 \\
\hline Participation of a Domestic National (or sub-national) DB & $\begin{array}{l}1.54^{* * * *} \\
{[0.22]}\end{array}$ & $\begin{array}{c}-0.01 \\
{[0.28]}\end{array}$ & $\begin{array}{c}12.06^{* * *} \\
{[1.50]}\end{array}$ & $\begin{array}{l}7.15^{* * *} \\
{[2.19]}\end{array}$ & $\begin{array}{l}1.12^{* * *} \\
{[0.20]}\end{array}$ & $\begin{array}{c}0.16 \\
{[0.26]}\end{array}$ \\
\hline $\begin{array}{l}\text { Participation of a Domestic National (or sub-national) DB } \\
\text { * The lead bank is foreign }\end{array}$ & $\begin{array}{l}3.12^{* * * *} \\
{[0.68]}\end{array}$ & $\begin{array}{l}3.76^{* * * *} \\
{[0.71]}\end{array}$ & $\begin{array}{l}2.16 \\
{[3.16]}\end{array}$ & $\begin{array}{c}2.72 \\
{[3.72]}\end{array}$ & $\begin{array}{l}2.93^{* * *} \\
{[0.64]}\end{array}$ & $\begin{array}{l}3.39^{* * * *} \\
{[0.70]}\end{array}$ \\
\hline Participation of a Foreign or Global (or regional) DB & $\begin{array}{l}5.51^{* * *} \\
{[0.67]}\end{array}$ & $\begin{array}{l}3.85^{* * *} \\
{[0.64]}\end{array}$ & $\begin{array}{l}6.57^{* * *} \\
{[1.39]}\end{array}$ & $\begin{array}{l}3.12^{* *} \\
{[1.31]}\end{array}$ & $\begin{array}{l}5.63^{* * *} \\
{[0.65]}\end{array}$ & $\begin{array}{l}4.17^{* * *} \\
{[0.63]}\end{array}$ \\
\hline $\begin{array}{r}\text { Participation of a Foreign or Global (or regional) DB } \\
\qquad \text { The lead bank is foreign }\end{array}$ & $\begin{array}{l}-2.00^{* *} \\
{[0.82]}\end{array}$ & $\begin{array}{l}-0.95 \\
{[0.79]}\end{array}$ & $\begin{array}{l}-9.85^{* * *} \\
{[2.50]}\end{array}$ & $\begin{array}{l}-7.31^{* * *} \\
{[2.21]}\end{array}$ & $\begin{array}{l}-1.88^{* * *} \\
{[0.80]}\end{array}$ & $\begin{array}{l}-0.92 \\
{[0.79]}\end{array}$ \\
\hline The lender is foreign & $\begin{array}{l}-9.61^{* * *} \\
{[0.12]}\end{array}$ & $\begin{array}{l}-10.25^{* * *} \\
{[0.14]}\end{array}$ & & & & \\
\hline The lead bank is foreign & $\begin{array}{l}-0.34^{* * *} \\
{[0.12]}\end{array}$ & $\begin{array}{c}0.05 \\
{[0.13]}\end{array}$ & $\begin{array}{l}-5.21^{* * *} \\
{[0.38]}\end{array}$ & $\begin{array}{l}-3.83^{* * *} \\
{[0.47]}\end{array}$ & $\begin{array}{l}0.54^{* * *} \\
{[0.11]}\end{array}$ & $\begin{array}{l}0.78^{* * *} \\
{[0.13]}\end{array}$ \\
\hline 'Top’ industry for the lender & $\begin{array}{l}0.33^{* * * *} \\
{[0.05]}\end{array}$ & $\begin{array}{l}0.84^{* * * *} \\
{[0.07]}\end{array}$ & $\begin{array}{l}2.62^{* * *} \\
{[0.27]}\end{array}$ & $\begin{array}{l}3.37^{* * *} \\
{[0.33]}\end{array}$ & $\begin{array}{l}0.17^{* * *} \\
{[0.04]}\end{array}$ & $\begin{array}{l}0.75^{* * *} \\
{[0.06]}\end{array}$ \\
\hline Lender former lead bank for borrower & $\begin{array}{c}17.04^{* * * *} \\
{[0.58]}\end{array}$ & $\begin{array}{c}15.84^{* * * *} \\
{[0.65]}\end{array}$ & $\begin{array}{c}13.73^{* * * *} \\
{[0.72]}\end{array}$ & $\begin{array}{c}10.52^{* * * *} \\
{[0.77]}\end{array}$ & $\begin{array}{c}17.84^{* * * *} \\
{[0.79]}\end{array}$ & $\begin{array}{c}17.84^{* * *} \\
{[0.91]}\end{array}$ \\
\hline Lender former participant for borrower & $\begin{array}{c}43.86^{* * * *} \\
{[0.43]}\end{array}$ & $\begin{array}{c}41.75^{* * * *} \\
{[0.44]}\end{array}$ & $\begin{array}{c}47.90^{* * *} \\
{[0.41]}\end{array}$ & $\begin{array}{c}44.67^{* * *} \\
{[0.44]}\end{array}$ & $\begin{array}{c}40.34^{* * * *} \\
{[0.51]}\end{array}$ & $\begin{array}{c}38.20^{* * * *} \\
{[0.53]}\end{array}$ \\
\hline Lead bank is former lead bank for borrower & $\begin{array}{c}-0.65^{* * *} \\
{[0.06]}\end{array}$ & $\begin{array}{c}-1.49^{* * *} \\
{[0.08]}\end{array}$ & $\begin{array}{c}-2.31^{* * *} \\
{[0.22]}\end{array}$ & $\begin{array}{c}-4.28^{* * *} \\
{[0.23]}\end{array}$ & $\begin{array}{c}-0.41^{* * *} \\
{[0.05]}\end{array}$ & $\begin{array}{c}-1.05^{* * *} \\
{[0.06]}\end{array}$ \\
\hline Lender on syndicate with the lead bank in last five years & $\begin{array}{l}2.48^{* * * *} \\
{[0.05]}\end{array}$ & $\begin{array}{l}0.95^{* * * *} \\
{[0.06]}\end{array}$ & $\begin{array}{l}8.47^{* * *} \\
{[0.26]}\end{array}$ & $\begin{array}{l}2.70^{* * * *} \\
{[0.37]}\end{array}$ & $\begin{array}{l}1.89^{* * * *} \\
{[0.04]}\end{array}$ & $\begin{array}{l}0.98^{* * *} \\
{[0.06]}\end{array}$ \\
\hline Additional Controls: & & & & & & \\
\hline Borrower characteristics & NO & YES & NO & YES & NO & YES \\
\hline Syndicate characteristics & NO & YES & NO & YES & NO & YES \\
\hline Lead bank characteristics & NO & YES & NO & YES & NO & YES \\
\hline Lender characteristics & NO & YES & NO & YES & NO & YES \\
\hline Country-year characteristics & NO & YES & NO & YES & NO & YES \\
\hline Loan purpose dummies & YES & YES & YES & YES & YES & YES \\
\hline Country effects & YES & YES & YES & YES & YES & YES \\
\hline Year effects & YES & YES & YES & YES & YES & YES \\
\hline Industry (division) effects & YES & YES & YES & YES & YES & YES \\
\hline Observations & $3,200,923$ & $1,916,273$ & 408,835 & 282,127 & $2,792,088$ & $1,634,146$ \\
\hline Number of loans (packages) & 44,899 & 40,280 & 41,365 & 36,265 & 44,899 & 40,280 \\
\hline r2 & 0.31 & 0.33 & 0.31 & 0.34 & 0.25 & 0.26 \\
\hline
\end{tabular}


Table 9: Covenant violations

This table estimates the relationship between financial covenant violations and development bank's participation in syndicated loans (DB participant) during the three years following the loan inception. For the scope we consider the following as financial covenants: Debt/EBITDA, Interest coverage and Current ratio. Column Debt/EBITDA covenant violation (incl. EBITDA $<0$ ) also considers as covenant breaches the cases in which EBITDA is negative, while Debt/EBITDA covenant violation (excl. EBITDA $<0)$ excluded these cases. Variable definitions are provided in Table 4. Standard errors clustered by borrower are reported in parentheses. ***, **, and * denote statistical significance at the $1 \%, 5 \%$, and $10 \%$ levels, respectively.

\begin{tabular}{|c|c|c|c|c|}
\hline Dependent variable: & $\begin{array}{c}\text { Debt/EBITDA } \\
\text { covenant violation } \\
(\text { excl. EBITDA }<0)\end{array}$ & $\begin{array}{c}\text { Debt/EBITDA } \\
\text { covenant violation } \\
(\text { incl. EBITDA }<0 \text { ) }\end{array}$ & $\begin{array}{l}\text { Interest coverage } \\
\text { covenant violation }\end{array}$ & $\begin{array}{c}\text { Current ratio } \\
\text { covenant violation }\end{array}$ \\
\hline & $(2)$ & (3) & (4) & (4) \\
\hline DB participant & $\begin{array}{c}0.11 \\
{[0.08]}\end{array}$ & $\begin{array}{c}0.12 \\
{[0.08]}\end{array}$ & $\begin{array}{c}0.10 \\
{[0.07]}\end{array}$ & $\begin{array}{c}0.14 \\
{[0.12]}\end{array}$ \\
\hline The lead bank is a former lender & $\begin{array}{l}-0.01 \\
{[0.01]}\end{array}$ & $\begin{array}{l}-0.02 \\
{[0.01]}\end{array}$ & $\begin{array}{l}-0.02 \\
{[0.02]}\end{array}$ & $\begin{array}{c}0.06 \\
{[0.04]}\end{array}$ \\
\hline The lead bank is foreign & $\begin{array}{c}0.01 \\
{[0.04]}\end{array}$ & $\begin{array}{c}0.00 \\
{[0.04]}\end{array}$ & $\begin{array}{l}0.06^{*} \\
{[0.03]}\end{array}$ & $\begin{array}{c}0.01 \\
{[0.09]}\end{array}$ \\
\hline Reputation: lead to participant & $\begin{array}{l}-0.15^{* *} \\
{[0.06]}\end{array}$ & $\begin{array}{l}-0.14^{* *} \\
{[0.06]}\end{array}$ & $-0.15^{* * *}$ & {$[0.14]$} \\
\hline Reputation: reciprocal & $\begin{array}{c}0.02 \\
{[0.03]}\end{array}$ & $\begin{array}{l}-0.01 \\
{[0.03]}\end{array}$ & $\begin{array}{c}0.05 \\
{[0.04]}\end{array}$ & $\begin{array}{l}-0.04 \\
{[0.07]}\end{array}$ \\
\hline Borrower characteristics & YES & YES & YES & YES \\
\hline Syndicate characteristics & YES & YES & YES & YES \\
\hline Country-year characteristics & YES & YES & YES & YES \\
\hline Loan purpose dummies & YES & YES & YES & YES \\
\hline Lead bank effects & YES & YES & YES & YES \\
\hline Country effects & YES & YES & YES & YES \\
\hline Year effects & YES & YES & YES & YES \\
\hline Industry (division) effects & YES & YES & YES & YES \\
\hline $\begin{array}{l}\text { Observations } \\
\text { r2 }\end{array}$ & $\begin{array}{c}5,803 \\
0.12\end{array}$ & $\begin{array}{c}5,970 \\
0.14\end{array}$ & $\begin{array}{c}4,091 \\
0.23\end{array}$ & $\begin{array}{l}685 \\
0.56\end{array}$ \\
\hline
\end{tabular}


Figure 1: Distribution of (non-lead) lenders by rank level

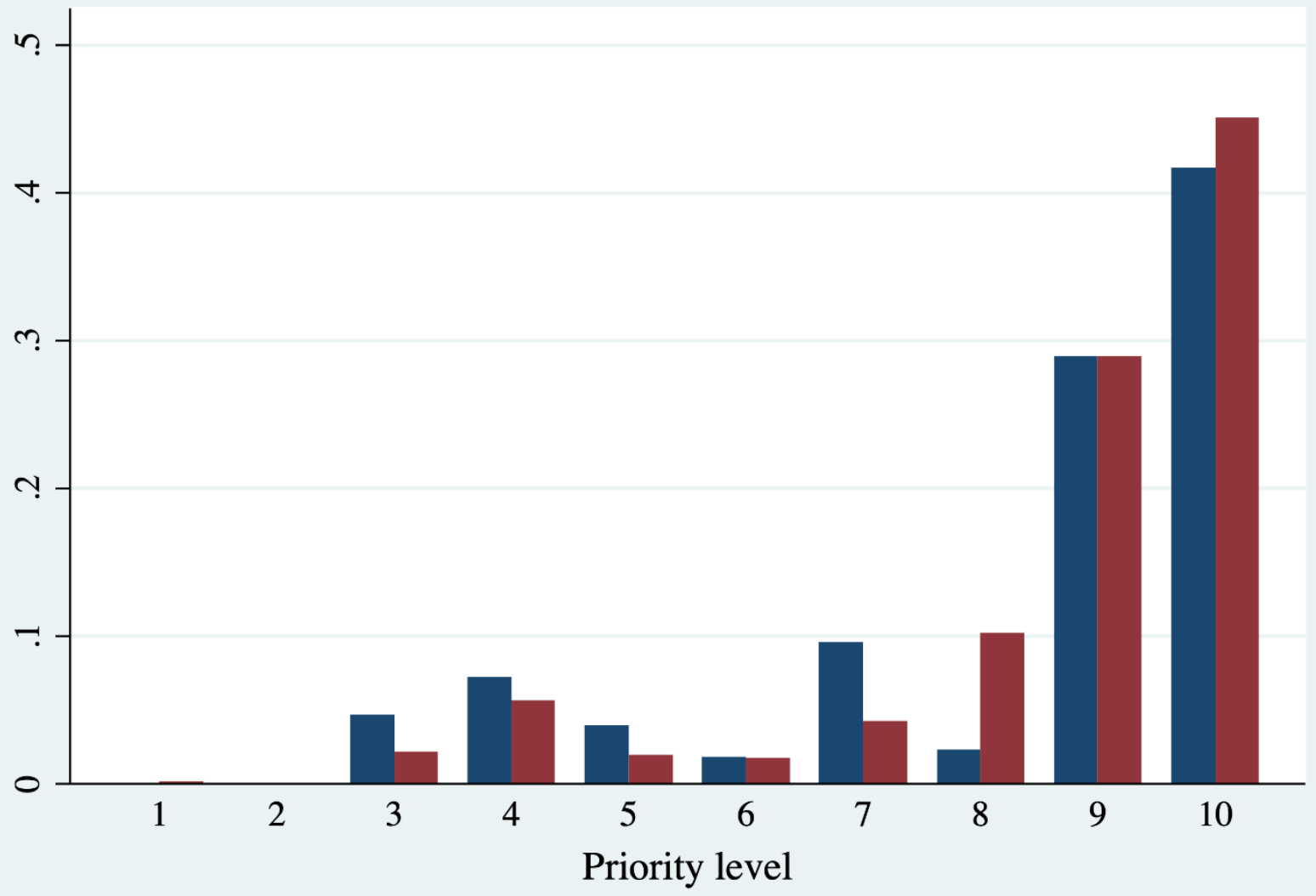

\section{Development banks $\quad$ Other lenders}




\section{Appendix A. Robustness Checks}

Table A1: (a) country-year and industry-year; (b) lead bank-year effects

This table reports the estimation results of the baseline model after adding additional fixed effects. Variable definitions are provided in Table 4 . Standard errors clustered by borrower are reported in parentheses. ***, **, and * denote statistical significance at the $1 \%, 5 \%$, and $10 \%$ levels, respectively.

\begin{tabular}{|c|c|c|c|c|c|}
\hline Dependent variable: & $\begin{array}{l}\text { Syndicate size } \\
\text { (number of } \\
\text { lenders) }\end{array}$ & $\begin{array}{c}\text { Lead Share } \\
\text { (per cent kept } \\
\text { by lead bank) }\end{array}$ & $\begin{array}{c}\text { Concentration } \\
\text { (Herfindahl) }\end{array}$ & $\begin{array}{l}\text { Number of } \\
\text { foreign } \\
\text { participant } \\
\text { lenders } \\
\end{array}$ & $\begin{array}{c}\text { Foreign Share } \\
\text { (per cent kept } \\
\text { by foreign } \\
\text { lenders }\end{array}$ \\
\hline & $(1 \mathrm{a})$ & $(2 a)$ & (3a) & \multicolumn{2}{|l|}{ (4a) } \\
\hline DB participant & $\begin{array}{l}4.36^{* * *} \\
{[0.35]}\end{array}$ & $\begin{array}{l}-1.93^{* *} \\
{[0.83]}\end{array}$ & $\begin{array}{c}-0.02^{* * *} \\
{[0.01]}\end{array}$ & $\begin{array}{l}3.24^{* * *} \\
{[0.30]}\end{array}$ & $\begin{array}{l}3.56^{* * *} \\
{[1.05]}\end{array}$ \\
\hline The lead bank is a former lender & $\begin{array}{l}0.22^{* * *} \\
{[0.07]}\end{array}$ & $\begin{array}{l}-0.88^{* *} \\
{[0.40]}\end{array}$ & $\begin{array}{c}-0.01^{* * *} \\
{[0.00]}\end{array}$ & $\begin{array}{c}-0.12^{* * *} \\
{[0.04]}\end{array}$ & $\begin{array}{l}-0.64^{*} \\
{[0.35]}\end{array}$ \\
\hline The lead bank is foreign & $\begin{array}{l}1.17^{* * * *} \\
{[0.13]}\end{array}$ & $\begin{array}{c}-2.46^{* * *} \\
{[0.67]}\end{array}$ & $\begin{array}{l}-0.01^{* *} \\
{[0.01]}\end{array}$ & $\begin{array}{l}1.86^{* * *} \\
{[0.10]}\end{array}$ & $\begin{array}{c}17.74^{* * *} \\
{[0.98]}\end{array}$ \\
\hline Reputation: lead to participant & $\begin{array}{l}7.81^{* * * *} \\
{[0.27]}\end{array}$ & $\begin{array}{c}-18.09^{* * *} \\
{[1.73]}\end{array}$ & $\begin{array}{c}-0.26^{* * * *} \\
{[0.02]}\end{array}$ & $\begin{array}{l}2.69^{* * *} \\
{[0.16]}\end{array}$ & $\begin{array}{c}1.83 \\
{[1.36]}\end{array}$ \\
\hline Reputation: reciprocal & $\begin{array}{l}0.51^{* * *} \\
{[0.11]}\end{array}$ & $\begin{array}{c}-24.18^{* * *} \\
{[1.39]} \\
\end{array}$ & $\begin{array}{c}-0.28^{* * *} \\
{[0.01]} \\
\end{array}$ & $\begin{array}{c}-0.47^{* * * *} \\
{[0.07]} \\
\end{array}$ & $\begin{array}{l}6.04^{* * *} \\
{[0.81]}\end{array}$ \\
\hline Borrower characteristics & YES & YES & YES & YES & YES \\
\hline Syndicate characteristics & YES & YES & YES & YES & YES \\
\hline Loan purpose dummies & YES & YES & YES & YES & YES \\
\hline Lead bank effects & YES & YES & YES & YES & YES \\
\hline Country-year effects & YES & YES & YES & YES & YES \\
\hline Industry-year effects & YES & YES & YES & YES & YES \\
\hline $\begin{array}{l}\text { Observations } \\
\text { r2 }\end{array}$ & $\begin{array}{c}43,473 \\
0.44 \\
\end{array}$ & $\begin{array}{c}13,699 \\
0.49 \\
\end{array}$ & $\begin{array}{c}13,699 \\
0.53 \\
\end{array}$ & $\begin{array}{c}43,473 \\
0.53 \\
\end{array}$ & $\begin{array}{c}13,699 \\
0.69 \\
\end{array}$ \\
\hline \multirow[t]{2}{*}{ Dependent variable: } & $\begin{array}{l}\text { Syndicate size } \\
\text { (number of } \\
\text { lenders) }\end{array}$ & $\begin{array}{c}\text { Lead Share } \\
\text { (per cent kept } \\
\text { by lead bank) }\end{array}$ & $\begin{array}{c}\text { Concentration } \\
\text { (Herfindahl) }\end{array}$ & $\begin{array}{l}\text { Number of } \\
\text { foreign } \\
\text { participant } \\
\text { lenders }\end{array}$ & $\begin{array}{c}\text { Foreign Share } \\
\text { (per cent kept } \\
\text { by foreign } \\
\text { lenders }\end{array}$ \\
\hline & (1b) & $(2 \mathrm{~b})$ & (3b) & \multicolumn{2}{|r|}{$(5 b)$} \\
\hline DB participant & $\begin{array}{l}4.70^{* * * *} \\
{[0.41]}\end{array}$ & $\begin{array}{l}-2.44^{* *} \\
{[1.00]}\end{array}$ & $\begin{array}{c}-0.03^{* * * *} \\
{[0.01]}\end{array}$ & $\begin{array}{l}3.56^{* * * *} \\
{[0.35]}\end{array}$ & $\begin{array}{l}5.03^{* * *} \\
{[1.19]}\end{array}$ \\
\hline The lead bank is a former lender & $\begin{array}{l}0.16^{* *} \\
{[0.07]}\end{array}$ & $\begin{array}{l}-0.69 \\
{[0.45]}\end{array}$ & $\begin{array}{c}-0.01^{* * *} \\
{[0.00]}\end{array}$ & $\begin{array}{c}-0.13^{* * *} \\
{[0.04]}\end{array}$ & $\begin{array}{l}-0.66^{*} \\
{[0.39]}\end{array}$ \\
\hline The lead bank is foreign & $\begin{array}{l}1.36^{* * * *} \\
{[0.15]}\end{array}$ & $\begin{array}{l}-2.11^{* *} \\
{[0.84]}\end{array}$ & $\begin{array}{c}-0.01 \\
{[0.01]}\end{array}$ & $\begin{array}{l}2.01^{* * *} \\
{[0.11]}\end{array}$ & $\begin{array}{c}16.98^{* * * *} \\
{[1.17]}\end{array}$ \\
\hline Reputation: lead to participant & $\begin{array}{l}9.45^{* * *} \\
{[0.32]}\end{array}$ & $\begin{array}{c}-21.10^{* * * *} \\
{[2.42]}\end{array}$ & $\begin{array}{c}-0.32^{* * * *} \\
{[0.02]}\end{array}$ & $\begin{array}{l}3.16^{* * * *} \\
{[0.17]}\end{array}$ & $\begin{array}{c}0.44 \\
{[1.70]}\end{array}$ \\
\hline Reputation: reciprocal & $\begin{array}{c}0.12 \\
{[0.12]}\end{array}$ & $\begin{array}{c}-23.36^{* * *} \\
{[1.54]} \\
\end{array}$ & $\begin{array}{c}-0.27^{* * * *} \\
{[0.01]} \\
\end{array}$ & $\begin{array}{c}-0.60^{* * * *} \\
{[0.07]} \\
\end{array}$ & $\begin{array}{l}5.84^{* * *} \\
{[0.86]}\end{array}$ \\
\hline Borrower characteristics & YES & YES & YES & YES & YES \\
\hline Syndicate characteristics & YES & YES & YES & YES & YES \\
\hline Loan purpose dummies & YES & YES & YES & YES & YES \\
\hline Country-year characteristics & YES & YES & YES & YES & YES \\
\hline Lead bank-year effects & YES & YES & YES & YES & YES \\
\hline Country effects & YES & YES & YES & YES & YES \\
\hline Industry effects & YES & YES & YES & YES & YES \\
\hline $\begin{array}{l}\text { Observations } \\
\text { r2 }\end{array}$ & $\begin{array}{c}40,280 \\
0.46\end{array}$ & $\begin{array}{c}12,322 \\
0.55\end{array}$ & $\begin{array}{c}12,322 \\
0.58\end{array}$ & $\begin{array}{c}40,280 \\
0.55\end{array}$ & $\begin{array}{c}12,322 \\
0.71\end{array}$ \\
\hline
\end{tabular}


Table A2: Baseline results based on public borrowers only

This table reports the estimation results of the baseline model after excluding observations referred to private borrowers. Variable definitions are provided in Table 4. Standard errors clustered by borrower are reported in parentheses. ${ }^{* *}, * *$, and $*$ denote statistical significance at the $1 \%, 5 \%$, and $10 \%$ levels, respectively.

\begin{tabular}{|c|c|c|c|c|c|}
\hline Dependent variable: & $\begin{array}{l}\text { Syndicate size } \\
\text { (number of } \\
\text { lenders) }\end{array}$ & $\begin{array}{l}\text { Lead Share } \\
\text { (per cent kept } \\
\text { by lead bank) }\end{array}$ & $\begin{array}{l}\text { Concentration } \\
\text { (Herfindahl) }\end{array}$ & $\begin{array}{l}\text { Number of } \\
\text { foreign } \\
\text { participant } \\
\text { lenders }\end{array}$ & $\begin{array}{l}\text { Foreign Share } \\
\text { (per cent kept } \\
\text { by foreign } \\
\text { lenders }\end{array}$ \\
\hline & $(1)$ & $(2)$ & (3) & (4) & (5) \\
\hline DB participant & $\begin{array}{l}4.91^{* * *} \\
{[0.45]}\end{array}$ & $\begin{array}{c}-2.43^{* *} \\
{[1.07]}\end{array}$ & $\begin{array}{c}-0.02^{* *} \\
{[0.01]}\end{array}$ & $\begin{array}{l}3.86^{* * * *} \\
{[0.40]}\end{array}$ & $\begin{array}{l}5.37^{* * *} \\
{[1.30]}\end{array}$ \\
\hline The lead bank is a former lender & $\begin{array}{l}0.21^{* *} \\
{[0.09]}\end{array}$ & $\begin{array}{l}-0.89^{*} \\
{[0.49]}\end{array}$ & $\begin{array}{c}-0.01^{* * *} \\
{[0.00]}\end{array}$ & $\begin{array}{l}-0.08 \\
{[0.05]}\end{array}$ & $\begin{array}{l}-0.21 \\
{[0.44]}\end{array}$ \\
\hline The lead bank is foreign & $\begin{array}{l}1.53^{* * *} \\
{[0.18]}\end{array}$ & $\begin{array}{l}-1.63^{*} \\
{[0.89]}\end{array}$ & $\begin{array}{l}-0.01 \\
{[0.01]}\end{array}$ & $\begin{array}{l}2.09^{* * *} \\
{[0.14]}\end{array}$ & $\begin{array}{c}16.46^{* * *} \\
{[1.27]}\end{array}$ \\
\hline Reputation: lead to participant & $\begin{array}{l}8.50^{* * * *} \\
{[0.36]}\end{array}$ & $\begin{array}{c}-21.00^{* * *} \\
{[2.22]}\end{array}$ & $\begin{array}{c}-0.31^{* * * *} \\
{[0.02]}\end{array}$ & $\begin{array}{l}2.92^{* * * *} \\
{[0.21]}\end{array}$ & $\begin{array}{c}1.82 \\
{[1.84]}\end{array}$ \\
\hline Reputation: reciprocal & $\begin{array}{l}0.40^{* * * *} \\
{[0.15]}\end{array}$ & $\begin{array}{c}-26.49^{* * *} \\
{[1.74]} \\
\end{array}$ & $\begin{array}{c}-0.31^{* * * *} \\
{[0.02]} \\
\end{array}$ & $\begin{array}{c}-0.64^{* * *} \\
{[0.09]} \\
\end{array}$ & $\begin{array}{l}6.23^{* * *} \\
{[1.04]}\end{array}$ \\
\hline Borrower characteristics & YES & YES & YES & YES & YES \\
\hline Syndicate characteristics & YES & YES & YES & YES & YES \\
\hline Country-year characteristics & YES & YES & YES & YES & YES \\
\hline Loan purpose dummies & YES & YES & YES & YES & YES \\
\hline Lead bank effects & YES & YES & YES & YES & YES \\
\hline Country effects & YES & YES & YES & YES & YES \\
\hline Year effects & YES & YES & YES & YES & YES \\
\hline Industry (division) effects & YES & YES & YES & YES & YES \\
\hline $\begin{array}{l}\text { Observations } \\
\text { r2 }\end{array}$ & $\begin{array}{c}28,007 \\
0.45\end{array}$ & $\begin{array}{c}8,684 \\
0.50\end{array}$ & $\begin{array}{c}8,684 \\
0.52\end{array}$ & $\begin{array}{c}28,007 \\
0.52\end{array}$ & $\begin{array}{c}8,684 \\
0.65\end{array}$ \\
\hline
\end{tabular}


Table A3: Only packages with a 'low' percentage of top_country and top_industry lenders

This table reports the estimation results of the baseline model. Variable definitions are provided in Table 4. Standard errors clustered by borrower are reported in parentheses. ${ }^{* * *}, * *$, and $*$ denote statistical significance at the $1 \%, 5 \%$, and $10 \%$ levels, respectively.

\begin{tabular}{|c|c|c|c|c|c|}
\hline Dependent variable: & $\begin{array}{l}\text { Syndicate size } \\
\text { (number of } \\
\text { lenders) }\end{array}$ & $\begin{array}{c}\text { Lead Share } \\
\text { (per cent kept } \\
\text { by lead bank) }\end{array}$ & $\begin{array}{c}\text { Concentration } \\
\text { (Herfindahl) }\end{array}$ & $\begin{array}{l}\text { Number of } \\
\text { foreign } \\
\text { participant } \\
\text { lenders } \\
\end{array}$ & $\begin{array}{c}\text { Foreign Share } \\
\text { (per cent kept } \\
\text { by foreign } \\
\text { lenders) }\end{array}$ \\
\hline & (1) & $(2)$ & (3) & (4) & (5) \\
\hline DB participant & $\begin{array}{l}4.82^{* * *} \\
{[0.43]}\end{array}$ & $\begin{array}{c}-2.80^{* * *} \\
{[0.97]}\end{array}$ & $\begin{array}{c}-0.03^{* * *} \\
{[0.01]}\end{array}$ & $\begin{array}{l}3.84^{* * *} \\
{[0.38]}\end{array}$ & $\begin{array}{l}5.38^{* * *} \\
{[1.19]}\end{array}$ \\
\hline The lead bank is a former lender & $\begin{array}{c}0.10 \\
{[0.08]}\end{array}$ & $\begin{array}{l}-0.66 \\
{[0.49]}\end{array}$ & $\begin{array}{c}-0.01^{* * *} \\
{[0.00]}\end{array}$ & $\begin{array}{c}-0.19^{* * *} \\
{[0.05]}\end{array}$ & $\begin{array}{l}-0.51 \\
{[0.46]}\end{array}$ \\
\hline The lead bank is foreign & $\begin{array}{l}1.36^{* * *} \\
{[0.15]}\end{array}$ & $\begin{array}{c}-2.68^{* * *} \\
{[0.77]}\end{array}$ & $\begin{array}{l}-0.01 \\
{[0.01]}\end{array}$ & $\begin{array}{l}1.96^{* * *} \\
{[0.11]}\end{array}$ & $\begin{array}{c}17.38^{* * * *} \\
{[1.06]}\end{array}$ \\
\hline Reputation: lead to participant & $\begin{array}{l}8.08^{* * * *} \\
{[0.32]}\end{array}$ & $\begin{array}{c}-22.48^{* * * *} \\
{[1.94]}\end{array}$ & $\begin{array}{c}-0.29^{* * * *} \\
{[0.02]}\end{array}$ & $\begin{array}{l}3.17^{* * *} \\
{[0.20]}\end{array}$ & $\begin{array}{c}2.40 \\
{[1.75]}\end{array}$ \\
\hline Reputation: reciprocal & $\begin{array}{l}0.62^{* * * *} \\
{[0.14]}\end{array}$ & $\begin{array}{c}-26.72^{* * * *} \\
{[1.56]} \\
\end{array}$ & $\begin{array}{c}-0.31^{* * *} \\
{[0.01]}\end{array}$ & $\begin{array}{c}-0.57^{* * *} \\
{[0.10]} \\
\end{array}$ & $\begin{array}{l}7.50^{* * * *} \\
{[1.03]}\end{array}$ \\
\hline Borrower characteristics & YES & YES & YES & YES & YES \\
\hline Syndicate characteristics & YES & YES & YES & YES & YES \\
\hline Country-year characteristics & YES & YES & YES & YES & YES \\
\hline Loan purpose dummies & YES & YES & YES & YES & YES \\
\hline Lead bank effects & YES & YES & YES & YES & YES \\
\hline Country effects & YES & YES & YES & YES & YES \\
\hline Year effects & YES & YES & YES & YES & YES \\
\hline Industry (division) effects & YES & YES & YES & YES & YES \\
\hline $\begin{array}{l}\text { Observations } \\
\text { r2 }\end{array}$ & $\begin{array}{c}29,958 \\
0.45\end{array}$ & $\begin{array}{c}9,326 \\
0.50 \\
\end{array}$ & $\begin{array}{c}9,326 \\
0.50\end{array}$ & $\begin{array}{c}29,958 \\
0.51 \\
\end{array}$ & $\begin{array}{c}9,326 \\
0.64 \\
\end{array}$ \\
\hline
\end{tabular}


Table A4: Baseline results (after excluding the 2007-2009 financial crisis)

This table reports the estimation results of the baseline model after excluding the 2007-2009 financial crisis. Variable definitions are provided in Table 4 . Standard errors clustered by borrower are reported in parentheses. ***, **, and * denote statistical significance at the $1 \%, 5 \%$, and $10 \%$ levels, respectively.

\begin{tabular}{|c|c|c|c|c|c|}
\hline Dependent variable: & $\begin{array}{l}\text { Syndicate size } \\
\text { (number of } \\
\text { lenders) }\end{array}$ & $\begin{array}{l}\text { Lead Share } \\
\text { (per cent kept } \\
\text { by lead bank) }\end{array}$ & $\begin{array}{c}\text { Concentration } \\
\text { (Herfindahl) }\end{array}$ & $\begin{array}{l}\text { Number of } \\
\text { foreign } \\
\text { participant } \\
\text { lenders } \\
\end{array}$ & $\begin{array}{c}\text { Foreign Share } \\
\text { (per cent kept } \\
\text { by foreign } \\
\text { lenders) }\end{array}$ \\
\hline & (1) & $(2)$ & (3) & $(4)$ & $(5)$ \\
\hline DB participant & $\begin{array}{l}4.97^{* * *} \\
{[0.47]}\end{array}$ & $\begin{array}{c}-2.62^{* * * *} \\
{[0.97]}\end{array}$ & $\begin{array}{c}-0.03^{* * *} \\
{[0.01]}\end{array}$ & $\begin{array}{l}3.70^{* * * *} \\
{[0.40]}\end{array}$ & $\begin{array}{l}4.69^{* * *} \\
{[1.17]}\end{array}$ \\
\hline The lead bank is a former lender & $\begin{array}{l}0.16^{* *} \\
{[0.08]}\end{array}$ & $\begin{array}{l}-0.76^{*} \\
{[0.44]}\end{array}$ & $\begin{array}{c}-0.01^{* * *} \\
{[0.00]}\end{array}$ & $\begin{array}{l}-0.12^{* *} \\
{[0.05]}\end{array}$ & $\begin{array}{c}-0.53 \\
{[0.41]}\end{array}$ \\
\hline The lead bank is foreign & $\begin{array}{l}1.33^{* * * *} \\
{[0.16]}\end{array}$ & $\begin{array}{c}-2.74^{* * *} \\
{[0.79]}\end{array}$ & $\begin{array}{l}-0.02^{*} \\
{[0.01]}\end{array}$ & $\begin{array}{l}1.95^{* * * *} \\
{[0.12]}\end{array}$ & $\begin{array}{c}16.99^{* * *} \\
{[1.08]}\end{array}$ \\
\hline Reputation: lead to participant & $\begin{array}{l}8.12^{* * * *} \\
{[0.29]}\end{array}$ & $\begin{array}{c}-22.32^{* * *} \\
{[1.85]}\end{array}$ & $\begin{array}{c}-0.30^{* * * *} \\
{[0.02]}\end{array}$ & $\begin{array}{l}2.82^{* * * *} \\
{[0.17]}\end{array}$ & $\begin{array}{l}3.43^{* *} \\
{[1.62]}\end{array}$ \\
\hline Reputation: reciprocal & $\begin{array}{l}0.40^{* * * *} \\
{[0.12]}\end{array}$ & $\begin{array}{c}-22.46^{* * * *} \\
{[1.57]}\end{array}$ & $\begin{array}{c}-0.27^{* * *} \\
{[0.01]}\end{array}$ & $\begin{array}{c}-0.61^{* * * *} \\
{[0.08]}\end{array}$ & $\begin{array}{l}4.39^{* * * *} \\
{[0.96]}\end{array}$ \\
\hline Borrower characteristics & YES & YES & YES & YES & YES \\
\hline Syndicate characteristics & YES & YES & YES & YES & YES \\
\hline Country-year characteristics & YES & YES & YES & YES & YES \\
\hline Loan purpose dummies & YES & YES & YES & YES & YES \\
\hline Lead bank effects & YES & YES & YES & YES & YES \\
\hline Country effects & YES & YES & YES & YES & YES \\
\hline Year effects & YES & YES & YES & YES & YES \\
\hline Industry (division) effects & YES & YES & YES & YES & YES \\
\hline $\begin{array}{l}\text { Observations } \\
\text { r2 }\end{array}$ & $\begin{array}{c}33,216 \\
0.43\end{array}$ & $\begin{array}{c}10,080 \\
0.46\end{array}$ & $\begin{array}{c}10,080 \\
0.48\end{array}$ & $\begin{array}{c}33,216 \\
0.51\end{array}$ & $\begin{array}{c}10,080 \\
0.64\end{array}$ \\
\hline
\end{tabular}


Table A5: Placebo test

This table reports the coefficient of “DB participant” dummy (randomly assigned) for 1,000 random resamples. Estimations are obtained from the same baseline specification of Table 4.

\begin{tabular}{|c|c|c|c|c|c|}
\hline & \multicolumn{5}{|c|}{ Dependent Variable } \\
\hline & $\begin{array}{c}\text { Syndicate size } \\
\text { (number of lenders) }\end{array}$ & $\begin{array}{l}\text { Lead Share (per } \\
\text { cent kept by lead } \\
\text { bank) }\end{array}$ & $\begin{array}{l}\text { Concentration } \\
\text { (Herfindahl) }\end{array}$ & $\begin{array}{l}\text { Number of foreign } \\
\text { participant lenders }\end{array}$ & $\begin{array}{c}\text { Foreign Share (per } \\
\text { cent kept by } \\
\text { foreign lenders) }\end{array}$ \\
\hline Mean & -0.011 & 0.030 & 0.000 & -0.004 & 0.024 \\
\hline S.E. & [0.138] & {$[0.818]$} & {$[0.008]$} & [0.085] & {$[0.780]$} \\
\hline Controls & [see Tab. 5] & [see Tab. 5] & [see Tab. 5] & [see Tab. 5] & [see Tab. 5] \\
\hline
\end{tabular}


Figure A1: Participation rate by lender (Lender PR)

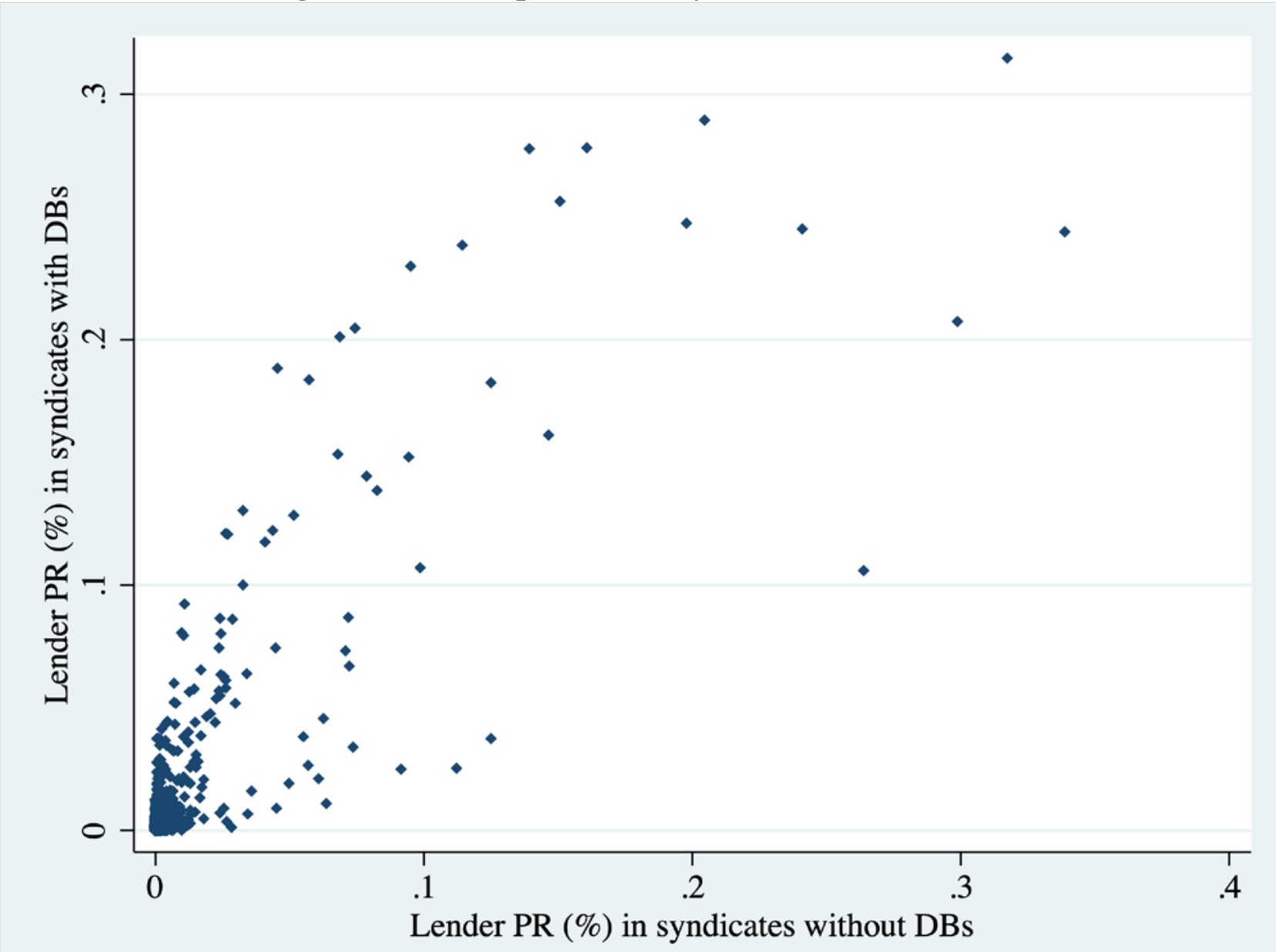


DB Type

Loan Volume

(US\$ mio)

Number

Foreign

of Loans

Share

(avg.)

\section{All development banks}

\section{National-level DFIs \\ Regional-Level DFIs \\ Global-Level DFIs \\ Sub-National Level DFIs}

\section{Individual development banks:}

Kfw Bankengruppe

Export Development Canada [Edc]

Banco Do Brasil

Ico [Instituto De Credito Oficial]

Development Bank Of Japan Inc

Korea Development Bank

Caisse De Depot Et Placement Du Quebec

Mcc Spa [Ex-Mediocredito Centrale]

Export-Import Bank Of The Republic Of China

China Development Bank [Cdb]

Bank Of Maharashtra

Export-Import Bank Of India

Bladex [Banco Latinoamericano De Comercio

Exterior Sa]

Business Development Bank Of Canada

European Investment Bank [Eib]

Export Import Bank Of The United States

Bancomext

Power Finance Corp Ltd
$2,429,845$

$2,333,567$

75,753

12,249

8,277

749,584

545,146

214,214

190,665

89,346

77,064

74,913

54,037

49,835

46,251

33,386

33,135

32,878

21,297

National-level DFIs

Regional-Level DFIs

19,922

National-level DFIs

18,893

National-level DFIs

16,691

15,979

National-level DFIs
1,988

44.0

1,855

42.4

94

22

17

21.4

73.0

82.1

64.3

56.6

491

70.3

56.2

67

127

15.1

138

46.1

50

5.1

23

35.7

116

37.4

44

39.7

38

0.9

55

16.4

43

82.1

35

8

58.9

\section{7}

20

12
14.6

54.4

0.1 


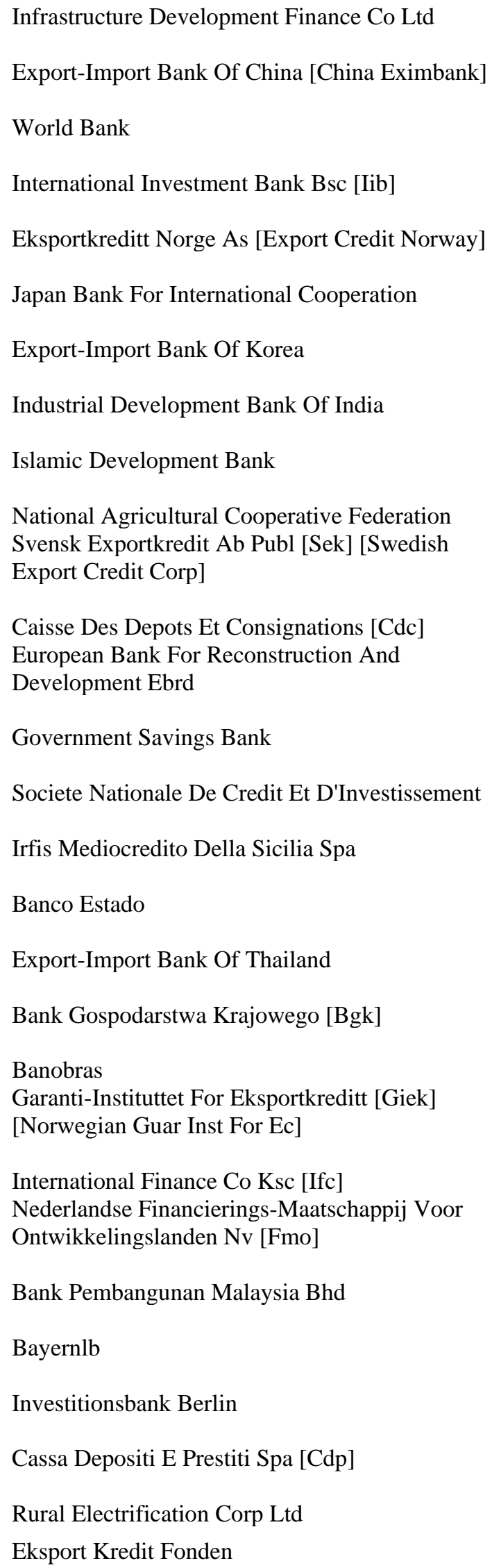

\begin{tabular}{|c|c|c|c|}
\hline National-level DFIs & 13,814 & 22 & 1.9 \\
\hline National-level DFIs & 10,979 & 17 & 35.2 \\
\hline Global-Level DFIs & 10,394 & 18 & 91.0 \\
\hline Regional-Level DFIs & 9,304 & 3 & \\
\hline National-level DFIs & 6,801 & 15 & 52.1 \\
\hline National-level DFIs & 6,561 & 14 & 79.5 \\
\hline National-level DFIs & 6,091 & 15 & 54.4 \\
\hline National-level DFIs & 6,056 & 4 & 0.0 \\
\hline Regional-Level DFIs & 5,845 & 3 & 0.0 \\
\hline National-level DFIs & 5,788 & 19 & 34.0 \\
\hline National-level DFIs & 4,804 & 8 & 85.2 \\
\hline National-level DFIs & 4,617 & 3 & 62.1 \\
\hline Regional-Level DFIs & 4,455 & 20 & 81.2 \\
\hline National-level DFIs & 4,297 & 4 & 11.6 \\
\hline $\begin{array}{l}\text { National-level DFIs } \\
\text { Sub-National Level }\end{array}$ & 3,719 & 1 & \\
\hline DFIs & 3,112 & 1 & 37.5 \\
\hline National-level DFIs & 3,050 & 13 & 86.0 \\
\hline National-level DFIs & 2,834 & 4 & 3.3 \\
\hline National-level DFIs & 2,688 & 2 & 100.0 \\
\hline National-level DFIs & 2,604 & 2 & 10.0 \\
\hline National-level DFIs & 2,514 & 13 & 9.1 \\
\hline Global-Level DFIs & 1,855 & 4 & 68.8 \\
\hline National-level DFIs & 1,647 & 6 & 57.4 \\
\hline $\begin{array}{l}\text { National-level DFIs } \\
\text { Sub-National Level }\end{array}$ & 1,585 & 2 & 0.0 \\
\hline $\begin{array}{c}\text { DFIs } \\
\text { Sub-National Level }\end{array}$ & 1,500 & 1 & \\
\hline DFIs & 1,402 & 2 & \\
\hline National-level DFIs & 1,354 & 3 & 55.2 \\
\hline National-level DFIs & 1,179 & 1 & 0.0 \\
\hline National-level DFIs & & & 89.7 \\
\hline
\end{tabular}


Nordic Investment Bank

Asian Development Bank

Banco Agrario De Colombia

Instituto Catalan De Finanzas [Icf]

Export Finance And Insurance Corp

Banca Del Mezzogiorno Mediocredito Centrale Spa

Lfa Forderbank Bayern

Banque Publique D'Investissement [Bpi France]

Turkiye Halk Bankasi As

African Export-Import Bank [Afreximbank]

Investitionsbank Des Landes Brandenburg

Turkiye Vakiflar Bankasi Tao [Vakifbank]

Indonesia Eximbank

Development Bank Of Southern Africa

Black Sea Trade And Development Bank [Bstdb]

Danish Export Credit Fund Eksport Kredit Fonden Ekf

Agence Francaise De Development [Afd]

Banco De La Provincia De Buenos Aires

National Federation Of Fisheries Cooperatives

Suhyup Bank

Compania Espanola De Creditos A La Exportacion

Cesce

Ecowas Bank For Investment And Development

China Export And Credit Insurance

African Development Bank [Afdb]

Finnish Fund For Industrial Cooperation

Inter-American Development Bank

Caf Bank

Sace Spa [Servizi Assicurativi Del Commercio

Estero]

Pak Oman Investment Co Ltd

\begin{tabular}{|c|c|}
\hline Regional-Level DFIs & 1,072 \\
\hline National-level DFIs & 1,064 \\
\hline National-level DFIs & 979 \\
\hline $\begin{array}{c}\text { Sub-National Level } \\
\text { DFIs }\end{array}$ & 935 \\
\hline National-level DFIs & 907 \\
\hline National-level DFIs & 865 \\
\hline Sub-National Level & \\
\hline DFIs & 823 \\
\hline National-level DFIs & 820 \\
\hline National-level DFIs & 693 \\
\hline Regional-Level DFIs & 650 \\
\hline Sub-National Level & \\
\hline DFIs & 505 \\
\hline National-level DFIs & 500 \\
\hline National-level DFIs & 420 \\
\hline National-level DFIs & 393 \\
\hline Regional-Level DFIs & 390 \\
\hline National-level DFIs & 378 \\
\hline National-level DFIs & 341 \\
\hline National-level DFIs & 310 \\
\hline National-level DFIs & 303 \\
\hline National-level DFIs & 252 \\
\hline Regional-Level DFIs & 250 \\
\hline National-level DFIs & 229 \\
\hline Regional-Level DFIs & 220 \\
\hline National-level DFIs & 212 \\
\hline Regional-Level DFIs & 200 \\
\hline Regional-Level DFIs & 150 \\
\hline National-level DFIs & 139 \\
\hline Regional-Level DFIs & 123 \\
\hline
\end{tabular}


Bank Kerjasama Rakyat Malaysia Bhd

European Investment Fund

International Bank For Economic Cooperation

East African Development Bank [Eadb]

Pak Libya Holding Co Ltd

North American Development Bank

Osterreichische Kontrollbank Aktiengesellschaft

Saudi-Pak Industrial And Agricultural Investment Co Pvt Ltd

Saudi Pak Industrial And Agricultural Investment Co Ltd

$\begin{array}{lccc}\text { National-level DFIs } & 101 & 1 & \\ \text { Regional-Level DFIs } & 96 & 1 & \\ \text { Regional-Level DFIs } & 92 & 1 & 16.7 \\ \text { Regional-Level DFIs } & 60 & 1 & 0.0 \\ \text { National-level DFIs } & 60 & 1 & 60.6 \\ \text { Regional-Level DFIs } & 45 & 1 & \\ \text { National-level DFIs } & 26 & 1 & \\ \text { National-level DFIs } & 10 & 1 & 0.0 \\ \text { National-level DFIs } & 6 & 1 & \end{array}$

